Sains Malaysiana 50(10)(2021): 3107-3126

http://doi.org/10.17576/jsm-2021-5010-23

\title{
Keterlarutan Selulosa, Pelarut dan Produk Selulosa yang Dijana Semula: Suatu Ulasan
}

(Cellulose Solubility, Solvent and Their Regenerated Cellulose Products: A Review)

\author{
Kushairi Mohd SAlleh, Sarani Zakaria*, Marhaini Mostapha, Umar Adli Amran, Wan NoOr AidaWATi \\ WAN NADHARI \& NUR AIN IBRAHIM
}

\begin{abstract}
Selulosa ialah polimer semula jadi yang boleh diperbaharui dan biasanya ditemui di dalam dinding sel tumbuhan. Interaksi hidrofobik yang kompleks serta sifat amfifilik menyebabkan ia sukar dilarutkan dan seterusnya membataskan penggunaannya secara menyeluruh. Pemahaman kepada struktur kimia dan fiziknya membolehkan proses pelarutan berlaku dengan penggunaan jenis pelarut yang bersesuaian. Namun, pelarut sedia ada bukanlah yang terbaik dan efisien terhadap pelarutan selulosa. Sehingga kini, kajian kepada jenis pelarut dan mekanisme pelarutan masih menjadi topik utama penyelidikan. Selulosa yang terlarut pula boleh dijana semula kepada produk fizikal yang lain, contohnya hidrogel, aerogel, kriogel dan xerogel. Produk yang dijana semula daripada selulosa yang terlarut boleh diacukan kepada pelbagai bentuk yang mempunyai struktur tulang yang kuat dan bersifat hidrofilik, bioserasi dan terbiodegradasi. Potensi dalam aplikasi yang pelbagai serta terbukti sebagai alternatif kepada polimer sintetik menjadikan polimer semula jadi ini berpotensi besar dalam bidang sains dan teknologi. Maka, ulasan kajian terhadap selulosa, jenis pelarut serta produk yang dijana semula daripadanya menjadi fokus dalam penulisan makalah ini.
\end{abstract}

ABSTRAK

Kata kunci: Pelarutan; pelarut tak-terbitan; pelarut terbitan; produk terjana semula

\section{ABSTRACT}

Cellulose is a naturally occurring polymer that is renewable and usually found in the plants' cell wall. Cellulose complex hydrophobic interactions and amphiphilic character render them difficult to be dissolved and consequently restricting total utilization. Understanding on their chemical structure and physical behaviour, introduction to suitable solvent allowing dissolution process to occur. Nonetheless, the current solvents are not the best and not as efficient as intended towards cellulose dissolution. Till date, research on solvent types and their reaction mechanism are still explored and characterized. The dissolved cellulose can be regenerated to different physical products such as hydrogel, aerogel, cryogel, and xerogel. The regenerated products from dissolved cellulose can be moulded into various shape with a strong skeletal structure and usually hydrophilic, biocompatible, and can be biodegraded. Cellulose potentials in various applications are proven as an excellent alternative to the synthetic polymer, making this naturally occurring polymer has huge potentials in science and technology. Therefore, a review on cellulose, different types of solvent and regenerated products from cellulose-based materials are the main focus in this manuscript.

Keywords: Derivatizing solvent; dissolving; non-derivatizing solvent; regenerated products

\section{PENGENALAN}

Pada tahun 1838, Anselme Payen telah memperkenalkan penggunaan perkataan selulosa yang merujuk kepada tisu tumbuhan yang telah ditulenkan, kemudiannya pulpa dirujuk sebagai 'selulosa' (Payen 1838). Walau bagaimanapun, istilah selulosa masih diguna pakai oleh penyelidik berdasarkan definisi asal yang diperkenalkan oleh Anselme Payen. Selulosa merupakan polimer jenis polisakarida yang mengandungi unit anhidroglukosa yang membentuk pautan pada $\beta$-1,4-D-ikatan glikosida yang paling banyak ditemui di dalam dinding sel tumbuhan (merangkumi $15-50 \%$ berat kering biojisim tumbuhan) (van de ven \& Godbout 2013). Selulosa merupakan polimer organik yang bersifat hidrofilik yang tidak mempunyai bau dan rasa, boleh diurai, tidak larut di dalam air dan kebanyakan pelarut organik 
(Salleh et al. 2019). Penggunaan selulosa asli adalah terbatas jika struktur kekisinya tidak diolah. Oleh itu melarutkan selulosa merupakan kaedah yang terbaik yang membolehkan ia diadun bersama dengan bahan serta polimer yang lain untuk dijana semula kepada produk yang lebih berprestasi. Antara faktor yang mempengaruhi keterlarutan selulosa ialah: struktur fibrilnya yang berhablur, wujudnya sistem inter- dan intra- ikatan hidrogen yang kuat yang mengelilingi rantai poliglukan, selulosa mempunyai darjah pempolimeran (DP) yang sangat tinggi dan interaksi hidrofobik (Labafzadeh 2015; Lindman et al. 2010).

Sifat selulosa yang tidak terlarut mengakibatkan kegunaannya yang sangat terbatas. Oleh itu, jika sumber boleh diperharui ini tidak dipelopori sepenuhnya maka pembaziran sumber alam yang kaya merupakan kerugian yang besar kepada pembangunan ekonomi negara. Maka, proses pelarutan merupakan kaedah terbaik dan proses yang terpenting dalam pengolahan struktur kekisi selulosa. Terdapat pelbagai jenis pelarut yang digunakan untuk melarutkan selulosa seperti pelarut tak-terbitan termasuklah akueus kompleks tak organik (cadoxen, cuen dan cuoxam), 10 bt.\% $\mathrm{NaOH}$ larutan akueus, asid mineral, garam tak oganik hidrat yang dicairkan, $\mathrm{N}, \mathrm{N}$ diametilasetamida (DMAC/LiCl) dan garam ammonia/ ammonium $\left(\mathrm{NH}_{3} / \mathrm{NH}_{4} \mathrm{SCN}\right)$. Manakala pelarut terbitan termasuklah $\mathrm{CF}_{3} \mathrm{COOH}, \mathrm{HCOOH}, N, N$-dimetilformamida (DMF) $/ \mathrm{N}_{2} \mathrm{O}_{4}$, DMSO/paraformaldehid, dan $\mathrm{NaOH} /$ $\mathrm{CS}_{2}$ (kaedah likat) (Luo \& Zhang 2013). Sehingga kini, kaedah likatan penghasilan viskosa merupakan teknik pelarutan yang sering digunakan untuk melarutkan selulosa meskipun ia telah dilaporkan sebagai tidak mesra alam kerana terdapat penggunaan karbon disulfida $\left(\mathrm{CS}_{2}\right)$ dan logam berat. Disebabkan keterbatasan pelarut sedia ada, maka kajian terhadap pelarut alternatif yang lebih mesra alam masih menjadi fokus utama penyelidikan. Pada sekitar tahun 2000, Zhou dan Zhang (2000) telah menemukan teknik pelarutan alternatif yang efisien dan mesra alam. Pelarut ini mengandungi campuran alkali seperti $\mathrm{NaOH}$ atau $\mathrm{LiOH}$ dengan urea atau tiourea. Kelebihan pelarut ini ialah, selulosa mampu dilarutkan dalam jangka masa yang lebih pendek berbanding pelarut selulosa yang lain pada suhu yang rendah antara -12 hingga $-5^{\circ} \mathrm{C}$ (Cai \& Zhang 2005; Zhou \& Zhang 2000). Penggunaan pelarut ini terbukti mampu menjana produk yang pelbagai seperti membran, hidrogel, aerogel dan kriogel (Salleh et al. 2020, 2019, 2018). Teknik pelarutan ini juga ternyata lebih ekonomi, efisien dan mesra alam berbanding dengan pelarut komersial sedia ada (Zhou et al. 2007). Sehingga kini, teknik pelarutan yang diperkenalkan ini dianggap sebagai alternatif yang terbaik dan kajian susulan kepada peningkatan keberkesanan sistem pelarutan ini masih diteruskan. Objektif utama kepada penggunaan pelarut yang efisien ialah untuk menambah baik dan mempelbagaikan pengolahan selulosa asli dan seterusnya dijana semula kepada produk berprestasi tinggi dalam pelbagai bidang dan aplikasi.

Penjanaan semula selulosa berlaku apabila selulosa semula jadi (selulosa I) dilarutkan ke dalam pelarut yang tertentu dan dijana semula (selulosa II) melalui interaksi fizikal atau kimia kepada bentuk fizikal yang lain. Antara produk penjanaan semula selulosa semula jadi yang menjadi fokus kepada kajian pada hari ini ialah hidrogel, aerogel, kriogel dan xerogel. Permintaan yang tinggi kepada produk penjanaan semula berasaskan selulosa adalah disebabkan oleh sifatnya yang boleh baharu serta kebolehuraian yang boleh dikawal mengikut keperluan aplikasi. Antara bidang kajian yang sering digunakan ialah bioperubatan dan pertanian (Jeddi \& Mahkam 2019; Maharjan et al. 2021; Wang et al. 2017). Dalam bidang perubatan, selulosa terbukti sebagai bahan bio-serasi yang bersifat tidak toksik, tak-imunogen serta tidak memberi kesan yang negatif kepada perumah (Vyas et al. 2017). Produk terjana semula selulosa terbukti sebagai alternatif yang baik kepada polimer sintetik malahan mampu menyaingi sifat bahan yang dihasilkan. Permintaan produk mesra alam dan bio-serasi yang kian meningkat menjadikan selulosa sumber alam yang sangat berharga yang perlu difahami dan dipelopori sifatnya. Ulasan kajian ini memfokuskan kepada sifat asas selulosa, pelarut yang boleh digunakan ke atasnya serta produk-produk yang boleh dijana semula daripadanya.

\section{STRUKTUR MOLEKULAR SELULOSA}

Selulosa merupakan polimer semula jadi linear yang terbina daripada polisakarida semi-hablur homopolimer 1,4- $\beta$-D-anhidroglukopiranosa (Atalla \& Isogai 2010). Struktur makromolekul selulosa terbina daripada unit berulang glukosa yang menunjukkan kepelbagaian senibina, reaktiviti dan fungsi. Merujuk kepada Rajah 1, unit ulangan selulosa ialah selulobios. Setiap unit glukosa yang kedua akan berputar $180^{\circ}$ secara sterik dengan jirannya, maka, ia boleh dikelaskan sebagai glukosa homopolimer sindiotaktik atau glukosa homopolimer anisotaktik. Homopolimer asimetri mempunyai dua unit-hujung yang ketara iaitu hujung bukan penurun dan hujung penurun. Hujung bukan penurun mempunyai kumpulan - $\mathrm{OH}$ tambahan pada $\mathrm{C} 4$, kumpulan hidroksil pada $\mathrm{C} 1$ terminal ialah hemiasetal dengan hujung penurun yang mempunyai fungsi karbonil (penurun) (Glasser 2008; Labafzadeh 2015). 


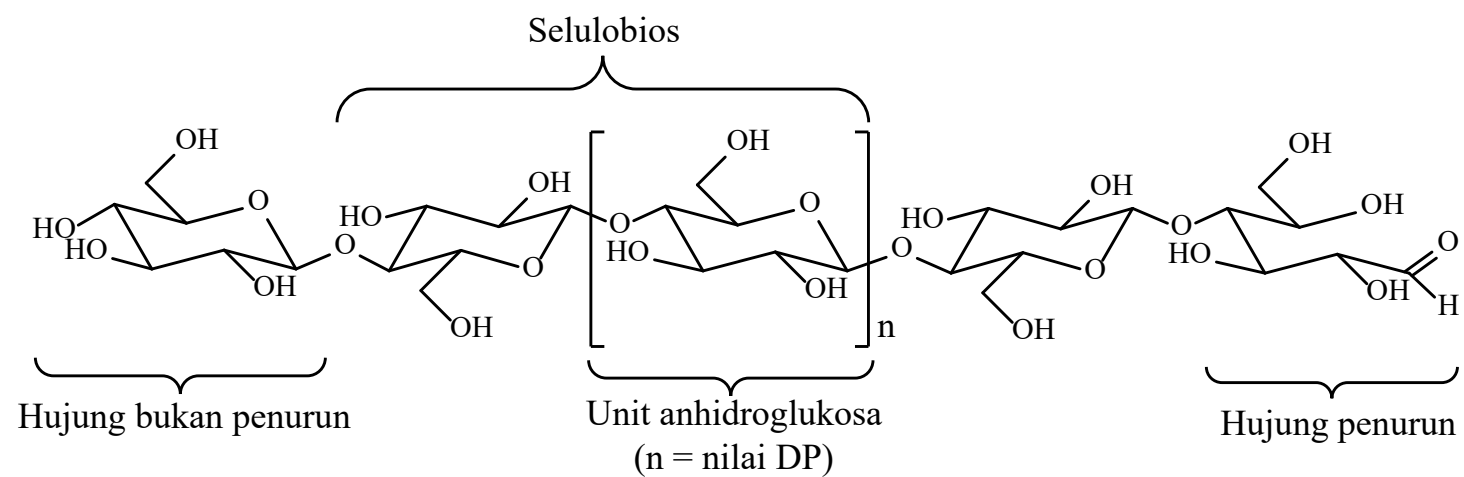

RAJAH 1. Struktur kimia selulosa

Analisis seperti spektroskopi inframerah (IR), sinar-X kristalografi dan resonans magnet nukleus (NMR) telah membuktikan bahawa gelang unit anhidroglukosa (AGU) berbentuk kerusi jenis $4 \mathrm{C} 1$, sebagai contoh kumpulan hidroksil bebas terletak secara melintang, manakala hidrogen atom berada pada posisi menegak (Labafzadeh 2015). Seperti yang dapat dilihat dalam Rajah 1, setiap unit berulang mengandungi tiga kumpulan hidroksil iaitu pada C2, C3 dan C6. Setiap kumpulan hidroksil ini mampu membentuk ikatan hidrogen antara rantai selulosa (inter-) yang memberi kesan terhadap sifat fizikalnya (Salleh et al. 2020). Ikatan intra- antara kumpulan hidroksil dan oksigen pada gelang molekul menstabilkan rangkaian yang membolehkan ia membentuk rantaian selulosa yang linear, memperbaik sifat mekanikal dan kestabilan terma. Sebaliknya, ikatan inter- bertanggungjawab kepada penyusunan antara rantai, yang seterusnya mempengaruhi keteraturan sistem (Gan et al. 2020; Salleh et al. 2020, 2019).

Kumpulan hidroksil yang terdapat pada makromolekul selulosa terlibat dalam beberapa ikatan hidrogen inter- dan intramolekular seperti yang ditunjukkan pada Rajah 2, yang menghasilkan pelbagai susunan hablur. Empat alomorf hablur yang berbeza dikenal pasti berdasarkan ciri corak pembelauan sinar-X
(XRD) dan fasa-pepejal 13C spektrum NMR iaitu selulosa I, II, III dan IV (Park et al. 2010). Selulosa asli atau dikenali sebagai selulosa I merupakan selulosa yang dijana tanpa rawatan atau melalui proses pengubahsuaian. Struktur metastabilnya yang termodinamik boleh ditukar kepada selulosa II atau III (Moon et al. 2011). Selulosa II boleh diperoleh dengan dua cara yang berbeza iaitu melalui rawatan alkali terhadap selulosa I atau dengan proses penjanaan semula (pelarutan dan selepas penghabluran semula). Proses pembalikan semula selulosa II kepada I dianggap mustahil, walau bagaimanapun, sebahagian selulosa natrium (terhasil daripada proses meserisasi dengan pelarut $\mathrm{NaOH}$ ) mampu bertukar semula kepada selulosa I. Selulosa III pula diperoleh dengan melakukan rawatan terhadap selulosa I atau II dengan menggunakan cecair ammonia pada suhu $-30{ }^{\circ} \mathrm{C}$ diikuti dengan penghabluran semula melalui proses penyejatan dengan pembebasan gas ammonia (Davis et al. 1943; Sarko et al. 1976). Selulosa IV pula terbentuk dengan merawat selulosa III dengan gliserol pada suhu yang tinggi $\left(260^{\circ} \mathrm{C}\right)(\mathrm{Klemm}$ et al. 1998; O’Sullivan 1997). Selalunya struktur molekul selulosa mewakili molekul separa lentur yang boleh digambarkan sebagai rantaian seakan cacing bagi rantaian pendek.

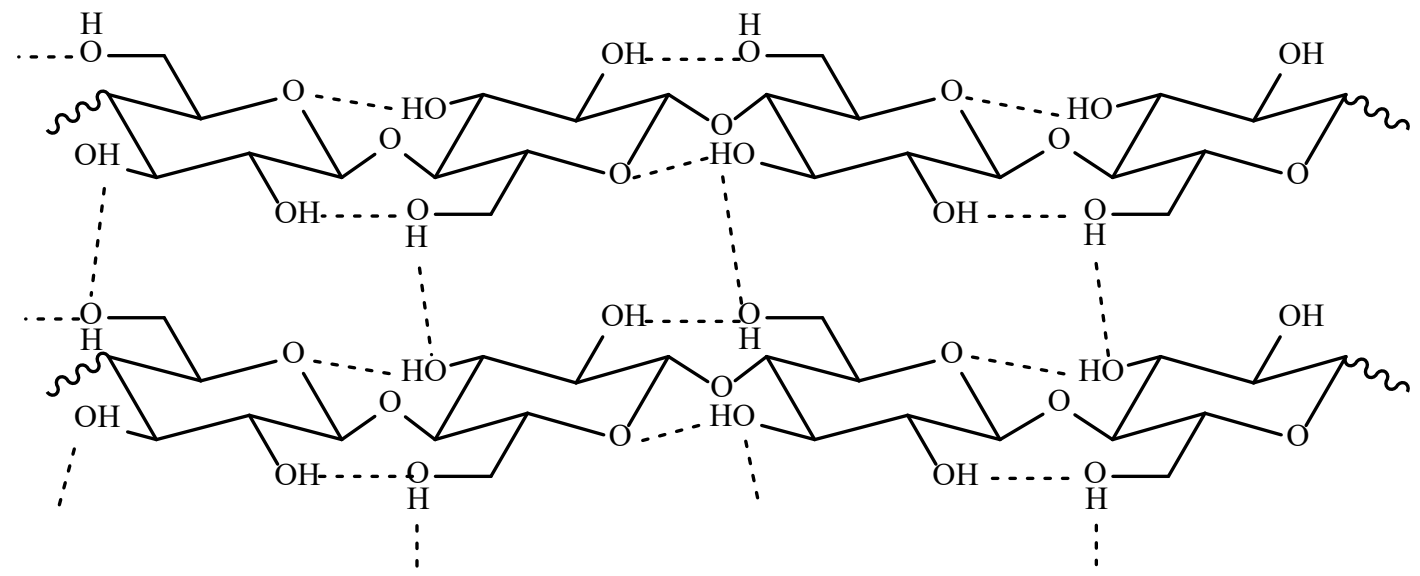

RAJAH 2. Inter- dan intramolekular ikatan hidrogen pada struktur molekular selulosa (garis putus-putus) 
Kebiasaannya, selulosa asli mempunyai darjah pempolimeran bagi glukosa unit (DP) sekitar 10000 hingga 15000 , bergantung kepada sumber selulosa itu sendiri (Shen 2010). Jadual 2 menunjukkan kepelbagaian DP untuk sumber selulosa yang berbeza. Selulosa semula jadi sentiasa wujud sebagai poliserakan, iaitu panjang rantainya yang tidak sekata. Maka, adalah sukar untuk memberikan nilai DP yang jitu bagi satu sumber selulosa yang sama. Dapatan nilai DP selalunya digunakan sebagai rujukan untuk disesuaikan dengan pelarut yang akan digunakan. Selulosa asli mempunyai DP yang lebih tinggi berbanding dengan selulosa yang terawat dan terubahsuai. Struktur morfologi selulosa banyak bergantung dengan DP selulosa itu sendiri. Pengelasan selulosa berdasarkan DP pula dibahagikan kepada tiga jenis iaitu alfa, beta dan gamma-selulosa. Struktur kimia bagi alfa, beta dan gamma-selulosa adalah sama namun dari segi fizikal ia tidak sama. Sebagai contoh, struktur alfa-selulosa mempunyai tetali misel, gamma-selulosa pula wujud sebagai fasa serakan tanpa unsur struktur yang nyata. Beta-selulosa tidak dapat dikelaskan secara terus daripada mikrograf elektron, namun analisis XRD menunjukkan persamaan dengan alfa-selulosa. Ini menunjukkan terdapat tetali misel yang tidak teratur dan pecah pada beta-selulosa yang mempunyai rantaian pendek (Wolfrom 1955). Tambahan lagi, perbezaan alfa, beta dan gamma-selulosa juga dapat dilihat berdasarkan keterlarutannya di dalam $17.5 \% \mathrm{NaOH}$. Alfa-selulosa (DP $>200$ ) tidak boleh dilarutkan di dalam $17.5 \% \mathrm{NaOH}$. Betaselulosa $(20<\mathrm{DP}<200)$ boleh dilarutkan di dalam $17.5 \%$ $\mathrm{NaOH}$, namun beta-selulosa boleh dimendakkan semula daripada larutan $\mathrm{NaOH}$. Gamma-selulosa $(10<\mathrm{DP}<30)$ boleh dilarutkan di dalam $17.5 \% \mathrm{NaOH}$ dan tidak boleh dimendakkan semula daripada larutan $\mathrm{NaOH}$ (Sixta 2006). Walaupun Gamma-selulosa mempunya DP hampir sama dengan hemiselulosa yang mempunyai rantaian gula dari glukosa, namun strukturnya berbeza kerana semua jenis selulosa sama ada alfa, beta atau gamma-selulosa adalah polimer yang tidak bercabang.

JADUAL 2. Purata DP berdasarkan sumber selulosa yang berbeza

\begin{tabular}{lcc}
\hline Selulosa & Purata DP & Rujukan \\
\hline Pulpa kayu & $692-1158$ & (Guo et al. 2010) \\
Pulpa kayu keras & 800 & (Kono \& Fujita 2012) \\
Pulpa tebu & 651 & (Guo et al. 2010) \\
Linter kapas & $392-960$ & (Guo et al. 2010) \\
Kenaf terluntur & 1917 & (Padzil et al. 2018) \\
Tandan kosong kelapa sawit terluntur & 2144 & (Salleh et al. 2018) \\
Rami tulen & 1600 & (Kono \& Fujita 2012) \\
\hline
\end{tabular}

\section{KETERLARUTAN SELULOSA}

Pemahaman struktur kimia dan pengelasan selulosa berdasarkan DP tidak mencukupi untuk memahami keterlarutan selulosa di dalam pelarut. Penggunaan selulosa dalam sektor pembuatan masih terbatas kerana ia sukar dilarutkan dalam kebanyakan pelarut organik mahupun tak organik. Terdapat banyak faktor yang mempengaruhi keterlarutan selulosa, namun, tiada faktor yang konkrit mengapa selulosa sukar dilarutkan. Maka, disebabkan ini, kajian terhadap pelarut yang digunakan untuk melarutkan selulosa masih aktif sehingga hari ini.
Antara faktor yang telah digariskan terhadap keterbatasan proses pelarutan selulosa berdasarkan kajian yang lepas ialah: struktur fibrilnya yang berhablur, wujudnya sistem inter- dan intra- ikatan hidrogen yang kuat yang mengelilingi rantai poliglukan dan selulosa mempunyai DP yang terlalu tinggi (kurang bahagian boleh capai oleh pelarut) serta interaksi hidrofobik (Labafzadeh 2015). Selain itu, kumpulan - $\mathrm{OH}$ pada C6 merupakan hidroksil utama yang membentuk ikatan hidrogen intermolekular, maka, kebolehcapaian pelarut terhadap kumpulan ini merupakan faktor 
yang membataskan keterlarutan selulosa. Dengan kata lain, jumlah kumpulan bebas $-\mathrm{OH}$ pada $\mathrm{C} 6$ lebih mempengaruhi keterlarutan selulosa berbanding dengan kumpulan bebas - OH pada C2 dan C3 (Itagaki et al. 1997; Kondo 1997). Walaupun kehabluran dan DP selulosa mungkin sedikit sebanyak mempengaruhi keterlarutan selulosa, namun, terdapat beberapa kajian lepas yang menafikan hubungan di antara mekanisme ikatan hidrogen dengan keterlarutan selulosa yang rendah. Justifikasi dilakukan oleh Lindman et al. (2010) yang membandingkan dekstran, yang mempunyai kapasiti ikatan hidrogen yang sama dengan selulosa, namun ia mudah larut di dalam air. Contoh lain yang digariskan beliau ialah metil dan hidroksietil selulosa yang sangat mudah larut di dalam air walaupun kapasiti ikatan hidrogennya lebih tinggi berbanding selulosa.

Hakikatnya, sifat amfifilik (mempunyai kawasan berkutub dan tidak berkutub) dan interaksi bahagian hidrofobik selulosa merupakan faktor utama yang mempengaruhi keterlarutan selulosa (Lindman et al. 2010; Medronho et al. 2012). Untuk polimer yang mempunyai berat molekular yang tinggi, walau dengan sedikit sifat amfifilik, ia sangat mempengaruhi sifatnya (cth: keterlarutan). Perkumpulan-sendiri amfifilik bukan sahaja berlaku pada surfaktan mahupun lipid, terdapat bukti yang kukuh ia juga berlaku pada gegelang glukosa selulosa. Sebagai contoh, siklodekstrin mempunyai keterlarutan akueus yang tinggi, pada masa yang sama ia mampu digabungkan pada bahagian molekul dalamannya yang sangat tidak berkutub yang memiliki permukaan dalaman yang agak hidrofobik. Ini menunjukkan terdapat kekutuban yang berbeza-beza pada rantai gegelang glukosa. Bahagian hidrofobik selulosa pula cenderung untuk memegang antara satu sama yang lain di dalam persekitaran akueus. Ini menyebabkan keterlarutan selulosa menjadi rendah. Walau bagaimanapun, secara keseluruhannya, kekutuban selulosa tidak lebih mahupun kurang berbanding dengan polisakarida yang lain, posisi geometri berkutub dan tidak berkutub sangat mempengaruhi keterlarutan selulosa (Lindman et al. 2010).

Jika sifat amfifilik dan interaksi hidrofobik diambil kira terhadap tahap keterlarutan selulosa, maka: i) Keterlarutan selulosa boleh dipertingkatkan di dalam larutan yang juga bersifat amfifilik (berkutub dan tidak berkutub), sebagai contoh cecair ionik dan $\mathrm{N}$-metilmorfolin N-oksida (NMMO).

ii) Cosolute yang mampu melemahkan interaksi hidrofobik pada gegelang glukosa selulosa, sebagai contoh urea dan terbitannya juga mampu meningkatkan keterlarutan selulosa (Lindman et al. 2010).

\section{PELARUTAN SELULOSA}

Proses pelarutan selulosa merupakan proses yang terpenting sebelum penjanaan semula selulosa dapat dilakukan. Seperti yang dinyatakan sebelum ini, selulosa sukar untuk dilarutkan di dalam pelarut organik mahupun tak organik atas faktor-faktor tertentu. Maka kesesuaian pelarut yang digunakan mestilah memenuhi kriteria yang telah digariskan oleh kajian sebelum ini (Lindman et al. 2010). Namun, jika pelarut yang digunakan terbukti mampu melarutkan selulosa, tahap keterlarutan selulosa pula bergantung kepada sumber selulosa itu sendiri (pengaruh berat molekul, DP dan kehabluran). Walau bagaimanapun, mekanisme pembengkakan selulosa sewaktu proses pelarutan perlu difahami terlebih dahulu.

Kelakuan serabut selulosa yang direndam di dalam pelarut berubah berdasarkan lima mod (Cuissinat \& Navard 2006):

i) Mod 1 (pelarutan yang pantas memutuskan selulosa kepada serpihan seakan rod): apabila serabut selulosa menyentuh pelarut, ia menyepai seakan rod yang besar. Tiada proses pembengkakan yang kelihatan sewaktu pelarutan. Bahagian yang lemah, contohnya bahagian amorfus atau lowong selulosa paling mudah untuk diserang oleh pelarut.

ii) Mod 2 (pembengkakan yang besar disebabkan oleh penggelembungan dan pelarutan): bahagian amorfus serabut yang berliang mula membengkak dan saiznya bertambah. Fenomena in dipanggil sebagai 'penggelembungan'. Gelembung ini membesar kepada saiz maksimum dan kemudiannya pecah. Pada ketika ini, keseluruhan serabut selulosa sudah terlarut.

iii) Mod 3 (pembengkakan yang besar disebabkan oleh penggelembungan dan pelarutan separa): sama dengan Mod 2, gelembung mula membesar, namun sebelum ia sampai ke saiz maksimum, proses ini terhenti, maka, serabut selulosa kekal dalam bentuk ini namun ia tidak terlarut.

iv) Mod 4 (pembengkakan homogen, namun tidak larut): pelarut yang tidak sesuai membengkakkan serabut selulosa terlalu perlahan dan tidak melarutkannya. Serabut selulosa kekal dalam keadaan membengkak pada mod ini.

v) Mod 5 (tiada pembengkakan, dan tidak larut): hal ini berlaku apabila serabut tidak dimasukkan ke dalam larutan bukan pelarut.

Keberkesanan pelarut berkurangan berdasarkan proses pembengkakan yang digariskan daripada Mod 1 - 5. Berdasarkan kajian lepas yang dijalankan oleh Cuissinat et al. (2008a, 2008b) dan Cuissinat dan Navard (2008, 2006), mereka menyimpulkan bahawa, pembengkakan dan mekanisme pelarutan bergantung 
sepenuhnya pada struktur fizikal serabut selulosa, bukannya kepada pelarut (jika pelarut yang sama digunakan sebagai perbandingan). Kualiti pelarut akan menentukan mekanisme pembengkakan pada serabut selulosa (Mod 1 - 5).

Proses dan mekanisme pembengkakan selulosa sebelum ia terlarut di dalam pelarut amat penting dalam proses pelarutan selulosa. Pembengkakan yang maksimum merujuk kepada pembengkakan yang bukan hanya berlaku pada permukaan luar selulosa malahan pada tulang belakangnya juga. Pembengkakan berlaku dengan kehadiran agen pembengkak yang memasuki liang, diikuti dengan pemutusan ikatan hidrogen yang kebanyakannya berlaku pada bahagian amorfus.
Penembusan pelarut merubah struktur fizikal hablur selulosa, diikuti dengan pembengkakan tak berbalik, selulosa I bertukar kepada susunan yang lebih tak teratur (selulosa II) selepas penjanaan semula berlaku. Pada masa yang sama, pembengkakan berbalik boleh berlaku apabila struktur hablur selulosa I kekal selepas penjanaan semula (Leipner et al. 2000).

\section{PELARUT}

Kategori pelarut selulosa diringkaskan seperti pada Rajah 3. Pelarut selulosa boleh dikelaskan kepada dua kategori iaitu pelarut tak-terbitan dan pelarut terbitan. Pelarut tak-terbitan dipecahkan lagi kepada media akueus dan tak akueus.

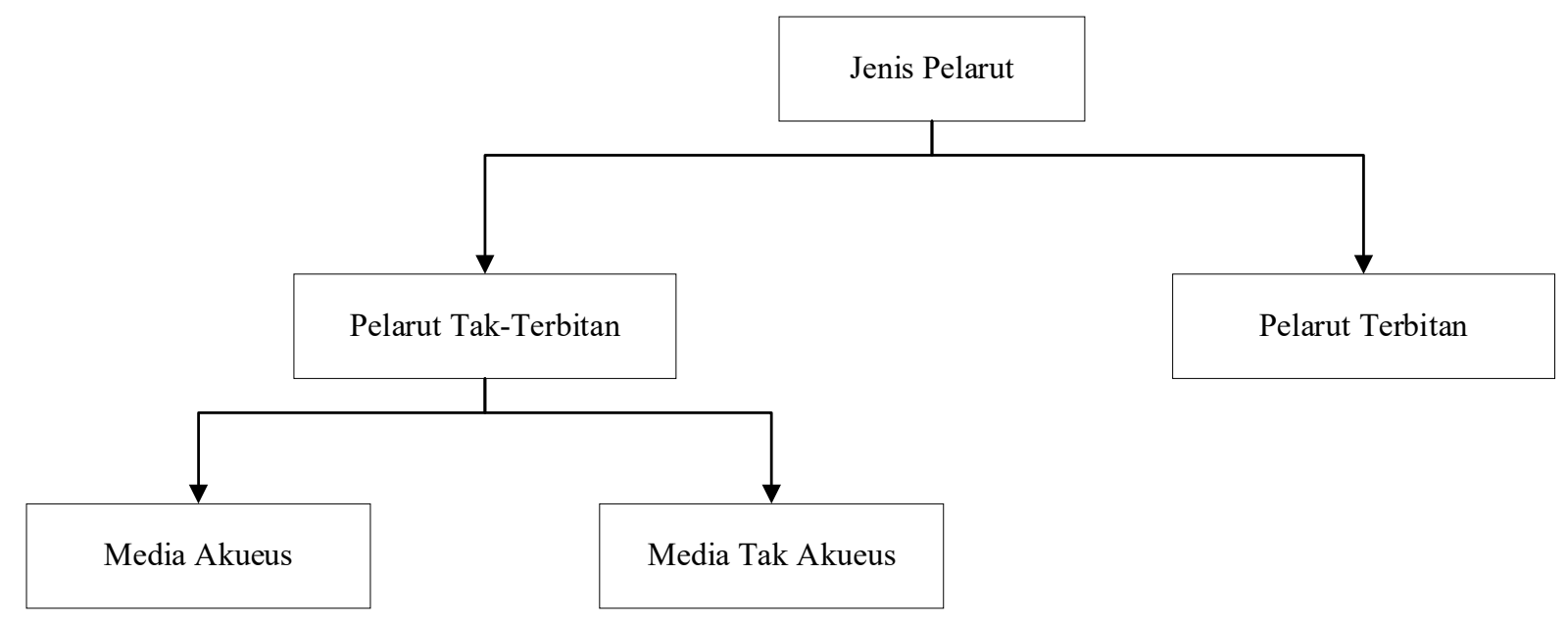

RAJAH 3. Pengelasan pelarut selulosa

\section{PELARUT TERBITAN}

Pelarut terbitan merujuk kepada pelarut yang mengaruhkan pengubahsuaian kovalen pada tulang belakang selulosa. Secara mudahnya, ia dirujuk sebagai pelarut selulosa secara pengubahsuaian kimia (Sen et al. 2013). Pelarutan berlaku kerana kumpulan berfungsi (cth: eter, ester, atau asetal terbitan yang tidak stabil) pada pelarut terbitan yang mengganggu ikatan hidrogen selulosa secara gabungan interaksi sterik dan mengurangkan kumpulan - $-\mathrm{OH}$ yang ada pada selulosa untuk pembentukan ikatan (El Seoud \& Heinze 2005; Heinze \& Koschella 2005). Jika jenis pelarutan ini yang digunakan, kumpulan berfungsi yang diperkenalkan pada selulosa mestilah mudah dilepaskan. Masalah utama bagi pelarut terbitan ialah kebolehasilan semula yang lemah kerana terdapat tindak balas sampingan dan struktur yang tidak dapat dikecam (El Seoud \& Heinze 2005).

\section{PELARUT TAK-TERBITAN}

Pelarut tak-terbitan pula merupakan pelarut yang memisahkan setiap serabut selulosa daripada satu sama lain melalui interaksi intermolekul tanpa pengubahsuaian kimia (Heinze \& Koschella 2005). Secara mudahnya, ia dirujuk sebagai pelarut selulosa tanpa pengubahsuaian kimia (Sen et al. 2013). Walau bagaimanapun, bagi pelarut tak-terbitan, hanya sedikit pelarut yang sesuai digunakan untuk pelarutan selulosa. Ia dikategorikan 'tak-terbitan' kerana tiada ikatan kovalen bahan yang 
dikesan pada ${ }^{13} \mathrm{C}$ NMR selepas proses pelarutan. Namun, sesetengah pelarut tak-terbitan, reaktiviti pelarut yang tinggi menyebabkan wujudnya tindak balas sampingan serta pelarutan yang terhad (Kihlman et al. 2013). Selulosa juga mungkin beragregat, yang menyebabkan larutan tidak homogen yang menghalang tindak balas daripada berlaku dengan lengkap (Liebert et al. 2010). Meskipun begitu, penambahbaikan terhadap sistem pelarutan ini masih dilakukan kerana potensinya yang baik, mesra alam serta keberkesanan pelarutan yang ditunjukkan. Antara pelarut tak-terbitan selulosa ialah akueus inorganik kompleks kuprammonium hidroksida (cuam) dan kuprietilenadiamina hidroksida (cuen), akueus alkali/ urea, campuran cecair organik/garam tak organik dan ammonia/garam ammonium.

\section{AKUEUS}

Selulosa tidak boleh dilarutkan di dalam air meskipun polisakarida seperti kanji, amilopektin, inulin dan dekstran mudah dilarutkan. Maka, untuk pelarut akueus, campuran di antara garam tak organik dan air boleh digunakan sebagai pelarut yang berkesan terhadap selulosa. Antara pelarut yang paling dikenali bagi pelarut akueus tak-terbitan (logam kompleks) ialah cuam, cuen, 10 bt. $\% \mathrm{NaOH}$, asid mineral dan garam tak organik hidrat yang dicairkan. Membran yang terjana semula daripada larutan cuam mempunyai kualiti yang baik untuk kegunaan hemodialisis. Walau bagaimanapun, kebanyakan logam kompleks merubah sifat selulosa melalui proses pengoksidaan, malahan ia juga tidak stabil, berwarna, toksik serta sukar untuk mengenal pasti sifat larutan selulosanya (Zhou et al. 2004). Selain itu, selulosa juga boleh dilarutkan dengan menggunakan 10 bt.\% $\mathrm{NaOH}$ namun hanya sesuai bagi selulosa yang mempunyai DP $<200$ (Heinze \& Koschella 2005). Bagi pelarut akueus tak-terbitan, sistem alkali/urea merupakan fokus ulasan kajian, kerana ia terbukti berkesan dan lebih baik sistem pelarutannya berbanding pelarut akueus yang lain.

\section{PELARUT AKUEUS ALKALI/UREA}

Untuk memahami pelarut akueus alkali/urea, pemahaman tentang sejarah penggunaan alkali dalam proses pelarutan perlu diselusuri terlebih dahulu. Individu pertama yang melaporkan pelarutan selulosa dengan alkali ialah Davidson (1934). Berdasarkan penemuan yang dilakukan, beliau menyatakan pada suhu yang rendah pelarutan selulosa berlaku dengan lebih berkesan. Pelarutan berlaku pada julat kepekatan $\mathrm{NaOH} /$ air yang kecil (Davidson melaporkan 10 bt.\% NaOH) pada suhu $-5^{\circ} \mathrm{C}$. Namun, kajian Sobue et al. (1939) lebih kerap dijadikan rujukan kerana beliau memperkenalkan gambar rajah fasa ternari. Berdasarkan rajah fasa ternari, julat pelarutan yang diberikan ialah 7 - 10 bt. $\% \mathrm{NaOH}$ dengan julat suhu -5 hingga $1{ }^{\circ} \mathrm{C}$. Beliau merujuk julat ini sebagai 'keadaan - Q' dengan Q merujuk kepada Quellung (perkataan Jerman) yang bermaksud bengkak. Terdapat lima jenis alkali selulosa, atau Na-Sel (I,II,III,IV atau V) yang dikenal pasti oleh Sobue et al. (1939). Untuk lebih spesifik, kawasan yang sesuai untuk proses pelarutan ialah, pelarut yang mempunyai suhu kurang daripada 0 ${ }^{\circ} \mathrm{C}$ dengan kepekatan 8 bt. $\% \mathrm{NaOH}$.

Bagi pelarut alkali/urea pula, ia mula diperkenalkan sebagai pelarut mesra alam seawal tahun 2000 (Zhou \& Zhang 2000). Pelarut ini mengandungi campuran alkali seperti $\mathrm{NaOH}$ atau $\mathrm{LiOH}$ dengan urea atau tiourea. Kelebihan pelarut ini ialah, selulosa mampu dilarutkan dalam jangka masa yang singkat berbanding pelarut selulosa yang lain pada suhu yang rendah di antara -12 hingga $-5^{\circ} \mathrm{C}$ (Cai \& Zhang 2005; Zhou \& Zhang 2000). Berdasarkan kajian mereka, antara komposisi nisbah terbaik untuk pelarut alkali/urea termasuklah 6 bt. $\%$ $\mathrm{NaOH} / 4$ bt.\% urea, 7 bt.\% NaOH/12 bt.\% urea, 6 bt. $\%$ $\mathrm{NaOH} / 5$ bt.\% tiourea dan 4.6 bt.\% LiOH/15 bt.\% urea (Cai \& Zhang 2005; Zhang et al. 2002; Zhou \& Zhang 2000). Zhou et al. (2004) dalam kajiannya menyatakan apabila selulosa dilarutkan di dalam 6 bt.\% NaOH/4 bt. $\%$ urea, pada spektrum ${ }^{13} \mathrm{C}$ NMR, anjakan kimia karbon pada 103.9 ppm merujuk kepada $\mathrm{C} 1,79.2$ ppm untuk C4, 75.7 ppm untuk C3 dan C5, 74.0 ppm untuk C2 dan 60.7 ppm untuk C6 menyerupai selulosa yang dilarutkan di dalam larutan akueus 10 bt.\% NaOH. Pelarut alkali/ urea terbukti tidak tergolong dalam pelarut terbitan kerana tiada puncak baharu yang wujud pada ${ }^{13} \mathrm{C}$ NMR. Ini menunjukkan pelarutan akueus alkali/urea merupakan pelarut selulosa yang berlaku secara langsung, maka larutan selulosa terlarut dan parameter molekulnya boleh dikaji sifatnya.

$\mathrm{NaOH}$ dan urea dianggap sebagai pelarut selulosa yang baik kerana tidak toksik dan murah. Sewaktu proses pelarutan pada suhu rendah, penyejatan bahan kimia tidak berlaku. Ini membolehkan pengekalan udara yang bersih untuk pengeluaran pada skala yang besar. Produk sampingan yang terhasil sewaktu pelarutan akueus alkali/urea boleh diasingkan dan dikitar semula dengan mudah untuk penggunaan semula. Natrium sulfat $\left(\mathrm{Na}_{2} \mathrm{SO}_{4}\right)$ dan urea merupakan produk sampingan yang boleh diasingkan dengan penyejatan pantas diikuti dengan penghabluran yang berlaku kerana perbezaan keterlarutan yang ketara antara $\mathrm{Na}_{2} \mathrm{SO}_{4}$ dan urea. Secara kesimpulannya, alkali/urea merupakan pelarut teknologi 
hijau kerana ia terbukti tidak mencemarkan dan mudah dikitar semula (Qi et al. 2009).

Dalam sistem akueus alkali/urea, selulosa boleh dilarutkan dalam masa kurang daripada 2 min, malahan ia juga terbukti memerlukan beberapa saat sahaja untuk pelarutan selulosa memandangkan wujudnya kesan Weissenberg yang berlaku dalam masa $30 \mathrm{~s}$ sahaja. Kesan Weissenberg merupakan fenomena yang berlaku apabila larutan yang dikacau oleh rod pengacau mendekati dan menyeliputi rod pengacau bukannya menjauhinya. Fenomena ini menunjukkan jenis pelarut ini mempunyai proses pelarutan yang paling pantas berbanding dengan pelarut yang lain (Cai et al. 2008; Luo \& Zhang 2013). Selalunya, bergantung dengan jenis pelarut dan kesalingbolehtukaran polimer, pelarutan polimer yang lambat adalah kerana resapan pelarut yang perlahan dan diperbaik melalui proses pemanasan. Namun, dalam sistem pelarut alkali/urea, selulosa hanya boleh dilarutkan pada suhu yang rendah sahaja. Ini dibuktikan apabila menggunakan pelarut alkali/urea yang sama pada suhu bilik, selulosa tidak boleh dilarutkan. Proses pelarutan melalui penyejukan pelarut merujuk kepada aruhan pembentukan jaringan ikatan hidrogen di antara selulosa dengan komponen pelarut. Selulosa kompleks alkali/urea agak stabil pada suhu yang rendah, membentuk makromolekul selulosa di dalam larutan akueus.

Kumpulan penyelidikan Salleh et al. $(2019,2018)$ dan Wang (2008) mencadangkan had DP tertentu bagi pelarutan selulosa kerana terdapat selulosa yang mempunyai DP yang tinggi yang melebihi had yang sukar untuk dilarutkan. Jadual 3 menunjukkan had DP yang boleh dilarutkan di dalam alkali/urea. Daripada Jadual 3, semakin tinggi DP selulosa, pelarut yang lebih kuat diperlukan untuk melarutkan selulosa. Indikator yang menunjukkan pelarutan selulosa yang sempurna diperoleh apabila larutan selulosa itu jernih. Kebanyakan pulpa kayu komersial atau hampas kapas (linter) mempunyai DP sekitar 800, yang mana ia tidak mudah larut di dalam sistem alkali/urea seperti larutan 6 bt. $\% \mathrm{NaOH} / 4$ bt. $\%$ urea atau 7 bt.\% NaOH / 12 bt.\% urea.

JADUAL 3. DP dan anggaran had pelarutan selulosa I dengan pelbagai larutan

\begin{tabular}{lll}
\hline DP & $\mathrm{M}_{\mathrm{b}}\left(10^{-4}\right)$ & Komposisi \\
\hline 100 & 1.58 & Pelarutan 9\% NaOH \\
200 & 3.16 & Pelarutan 9\% NaOH \\
300 & 4.74 & $6 \% \mathrm{NaOH} / 4 \%$ urea \\
425 & 6.70 & $6 \% \mathrm{NaOH} / 4 \%$ urea \\
500 & 7.90 & $6 \% \mathrm{NaOH} / 5 \%$ tiourea \\
600 & 9.48 & $7 \% \mathrm{NaOH} / 12 \%$ urea \\
700 & 11.06 & $7 \% \mathrm{NaOH} / 12 \%$ urea \\
800 & 12.64 & $4.2 \% \mathrm{LiOH} / 12 \%$ urea \\
900 & 14.22 & $4.2 \% \mathrm{LiOH} / 12 \%$ urea \\
2000 & 31.60 & $4.2 \% \mathrm{LiOH} / 12 \%$ urea \\
2500 & 39.50 & $4.2 \% \mathrm{LiOH} / 12 \%$ urea \\
\hline
\end{tabular}

(Sumber: Wang 2008)

Rajah 4 menunjukkan mekanisme pelarutan selulosa di dalam sistem alkali/urea. Pertama, prapenyejukan alkali/urea $\left(-12\right.$ hingga $\left.-13{ }^{\circ} \mathrm{C}\right)$ diikuti dengan penyebaran selulosa di dalam pelarut pra- sejuk. Seperti yang ditunjukkan pada Rajah 4(a), rantai selulosa dikelilingi oleh alkali hidrat, urea hidrat dan air bebas. Ketiga-tiga komponen kimia ini menembusi ke dalam molekul selulosa dan memusnahkan ikatan 
inter- dan intra- hidrogen pada rantai selulosa. Rajah 4(b) pula menunjukkan ikatan hidrogen pada selulosa yang musnah yang menyebabkan pelarutan rantai selulosa di dalam pelarut alkali and urea hidrat. Pada fasa ini, selulosa menyerap alkali dan urea hidrat, diikuti dengan pembengkakan molekul selulosa. Rajah 4(c) menunjukkan alkali hidrat, urea hidrat dan air bebas membentuk lapisan luar pada rantai selulosa (juga dikenali sebagai kepungan kompleks) yang tersebar di dalam pelarut dan menyebabkan larutan selulosa menjadi telus.

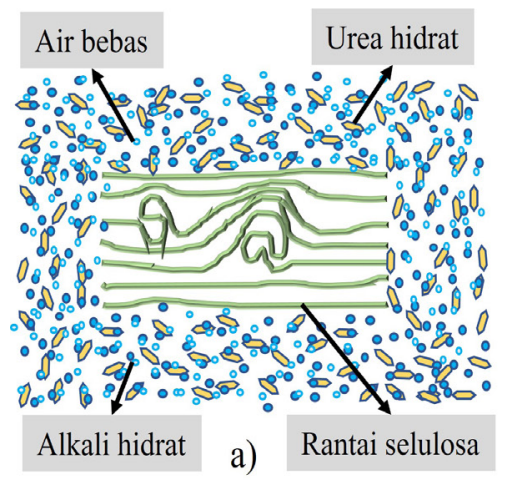

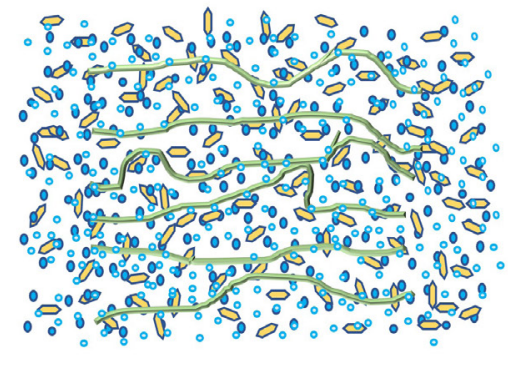

b)

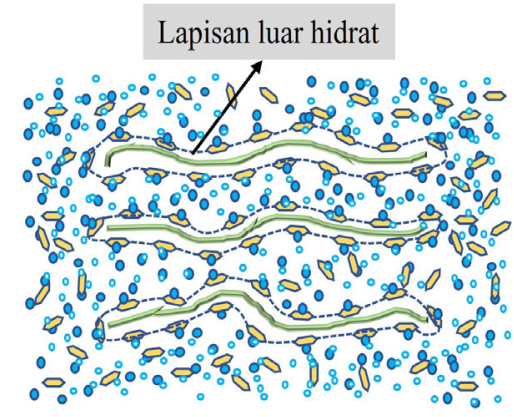

c)

RAJAH 4. Skematik proses pelarutan selulosa di dalam sistem akueus alkali/urea

Secara spesifik, mekanisme pelarutan selulosa di dalam pelarut alkali/urea melibatkan alkali (cth: $\mathrm{NaOH}$ atau $\mathrm{LiOH}$ ) hidrat, urea hidrat, air bebas dan selulosa yang akan membentuk kompleks yang istimewa (kepungan kompleks (KK)) di dalam larutan seperti yang ditunjukkan pada Rajah 4(c). Alkali memusnahkan ikatan interdan intra- hidrogen antara selulosa (Wang 2008). Pembentukan KK bergantung kepada urea dan alkali hidrat yang bertindak balas dengan rantaian selulosa. KK berkemungkinan merencatkan ikatan inter- dan intrahidrogen molekul selulosa melalui pembentukan alkali hidrat-terikat dengan rantai selulosa. Urea hidrat pada permukaan alkali hidrat-terikat dengan rantai selulosa untuk menghalang pengagregatan yang membolehkan selulosa dilarutkan dengan baik. Urea hidrat berfungsi sebagai penderma ikatan hidrogen dan reseptor antara molekul pelarut menghalang pengagregatan molekul selulosa yang seterusnya membolehkan pelarutan molekul selulosa berlaku (Wang 2008). Pada suhu rendah, pelarutan pantas selulosa dikaitkan dengan pembentukan struktur ikatan hidrogen yang baru di dalam sistem akueus. Kluster yang bersekutu dengan alkali, urea, dan air akan meningkat apabila suhu menurun. Ia terbukti apabila alkali hidrat lebih mudah tertarik kepada rantai selulosa melalui pembentukan jaringan ikatan hidrogen yang baharu pada suhu rendah. Manakala, urea hidrat boleh tersusun sendiri pada permukaan selulosa yang mempunyai ikatan hidrogen dengan alkali (cth:
$\mathrm{NaOH}$ atau LiOH) untuk pembentukan KK (Cai et al. 2008; Luo \& Zhang 2013). Struktur saluran KK seperti yang ditunjukkan pada Rajah 4(c) wujud seakan cacing di dalam sistem pelarut alkali/urea (Nagel et al. 2010).

Di dalam larutan akueus alkali/urea, pembentukan KK selulosa disalut oleh cengkerang urea pada kepekatan rendah melalui proses pasang-sendiri yang dinamik di antara molekul pelarut yang bersaiz kecil dengan makromolekul selulosa. Fenomena ini membolehkan pelarutan selulosa yang lebih berkesan berlaku. Memandangkan ia merupakan proses pasangsendiri yang dinamik, maka larutan selulosa itu sendiri berada dalam keadaan metastabil. Keadaan penyimpanan yang stabil untuk satu struktur KK selulosa ialah pada kepekatan selulosa yang rendah daripada $1.2 \mathrm{~g} / \mathrm{L}$ pada julat suhu 5 hingga $15{ }^{\circ} \mathrm{C}$ dengan masa penyimpanan kurang daripada 24 jam (Lue et al. 2011). Walau bagaimanapun, secara relatifnya, larutan selulosa ini tidak stabil dan sensitif terhadap banyak faktor seperti suhu, kepekatan selulosa dan tempoh simpanan kerana ia akan menyebabkan pengagregatan selulosa serta struktur KK yang dinamik juga akan musnah.

Sebenarnya semua alkali hidroksida boleh membantu proses pembengkakan selulosa. Pembengkakan maksimum pada kepekatan hidroksida yang diberi bergantung dengan sifat semula jadi ion logam, dalam susunan $\mathrm{Li}>\mathrm{Na}>\mathrm{K}>\mathrm{Rb}>\mathrm{Cs}$ berdasarkan tahap keberkesanannya. Kadar pembengkakan selulosa 
ditentukan berdasarkan saiz ion hidrat (saiz ion: $\mathrm{Li}<$ $\mathrm{Na}<\mathrm{K}<\mathrm{Rb}<\mathrm{Cs}$ ). Semakin besar ion hidrat, semakin sukar untuk ia menembusi selulosa dan semakin rendah kesan pembengkakannya (Petitpas 1948). Apabila kesan pembengkakan rendah, ia menyebabkan proses pelarutan semakin sukar untuk berlaku. Disebabkan ini, hanya $\mathrm{LiOH}$ dan $\mathrm{NaOH}$ sahaja yang digunakan secara meluas untuk proses pelarutan selulosa. Namun, di antara $\mathrm{LiOH}$ dengan $\mathrm{NaOH}$, keberkesanan pelarutan selulosa oleh LiOH adalah lebih baik berbanding $\mathrm{NaOH}$ (Padzil et al. 2015). Ini disebabkan oleh ion hidrat LiOH yang lebih kecil berbanding $\mathrm{NaOH}$, maka ia lebih mudah tembus ke dalam selulosa untuk proses pembengkakan dan diikuti dengan proses pelarutan. Ini terbukti apabila, pada DP yang lebih tinggi (Jadual 3), LiOH mampu melarutkan selulosa berbanding $\mathrm{NaOH}$. Meskipun begitu, secara relatifnya, harga pasaran $\mathrm{LiOH}$ jauh lebih mahal berbanding $\mathrm{NaOH}$. Ini sedikit sebanyak mengurangkan nilai komersial $\mathrm{LiOH}$ berbanding $\mathrm{NaOH}$ dalam sistem pelarut alkali/urea kepada penghasilan produk terjana semula.

\section{LARUTAN BUKAN AKUEUS}

Laporan pertama berkenaan dengan pelarut bukan akueus tak-terbitan terhadap selulosa ialah pada tahun 1934 oleh Charles Graenacher. Beliau menggunakan garam $\mathrm{N}$-alkilpiridinium untuk melarutkan selulosa sebagai media tindak balas kimia homogen (Graenacher 1934). Penggunaan pelarut bukan akueus tak-terbitan melibatkan sama ada pelarut tunggal (unikomponen), dwikomponen, trikomponen atau multikomponen. Antara pelarut unikomponen ialah asid trifluoroasetik, $N$-etilpiridinium klorida, $N$-metilmorfolin- $N$-oksida, trietilamina- $N$-oksida dan $N$-metilpiperidina- $N$-oksida (De Silva et al. 2016; Medronho et al. 2012; Mi et al. 2016). Penggunaan lebih daripada satu komponen pelarut bukan akueus tak-terbitan adalah untuk meningkatkan keberkesanan proses pelarutan dengan komponon berbeza yang memberikan pendekatan mekanisme yang berbeza. Hal ini memudahkan proses peleraian struktur molekul selulosa dan seterusnya memudahkan proses pelarutannya. Dwikomponen yang sering digunakan termasuklah dimetil sulfoksida (DMSO)/metilamina, paraformadehid/DMSO, $N, N$-dimetilasetamida/LiCl dan piridina/resosinol (Heinze \& Koschella 2005; Philipp et al. 1977). Manakala contoh bagi trikomponen ialah $\mathrm{NH}_{3} / \mathrm{NaCl} / \mathrm{DMSO}$, dietulamina/SO2/DMSO dan Etilenadiamina/NaI $/ N, N$-dimetilformamida (Heinze \& Koschella 2005; Philipp et al. 1977).

Pada tahun 2002, Swatloski et al. telah menerbitkan kajian tentang garam yang mencair di bawah suhu 100 ${ }^{\circ} \mathrm{C}$ (dikenali hari ini sebagai cecair ionik) sebagai pelarut selulosa. Melalui kajian ini, ia menjadi titik mula kepada kajian yang lebih mendalam tentang penggunaan cecair ionik terhadap pelarutan selulosa. Berdasarkan kajian beliau juga, cecair ionik terbaik untuk pengubahsuaian selulosa ialah garam 1-akil-3-metilimidazolium. Cecair ionik mampu melarutkan selulosa dan karbohidrat lain pada skala yang besar. Cecair ionik sangat berpotensi tinggi, sebagai contoh, 1-butil-3-metilimidazolium klorida ([BMIM]Cl) mampu melarutkan dengan baik bahan berselulosa dan lignin daripada pelbagai sampel kayu. Namun, terdapat faktor yang mengehadkan ia digunakan pada skala yang besar, contohnya penghasilannya melibatkan kos yang tinggi, kepekatan yang tak terkawal, sensitif terhadap lembapan dan proses pemurnian yang kurang baik (Delbecq et al. 2018). Sehingga kini masih tiada teori yang jitu yang dilaporkan mengenai mekanisme interaksi antara cecair ionik dengan polimer (Liebert et al. 2010).

\section{PENJANAAN SEMULA SELULOSA}

Penjanaan semula selulosa berlaku apabila selulosa asli (selulosa I) dilarutkan ke dalam pelarut yang tertentu dan selulosa yang terlarut dijana semula (selulosa II) melalui interaksi fizikal atau kimia kepada bentuk fizikal yang lain. Antara produk penjanaan semula selulosa yang sering menjadi fokus kepada kajian pada hari ini ialah hidrogel, aerogel, kriogel dan xerogel (Gan et al. 2020; Salleh et al. 2020, 2018). Meskipun setiap daripada produk yang dijana semula ini dihasilkan daripada sumber yang sama, namun penamaannya mungkin menjadi berbeza-beza mengikut teknik penghasilan yang berbeza. Untuk kes yang tertentu, teknik penghasilan yang sama digunakan namun penamaan produk menjadi berbeza kerana ia diterbitkan berdasarkan nama asal bahan mentah yang digunakan. Sebagai contoh, aeroselulosa merupakan terbitan daripada perkataan aerogel, namun namanya diolah kerana bahan mentah yang digunakan berasal daripada selulosa (Innerlohinger et al. 2006). Penjanaan semula selulosa kepada produk yang pelbagai telah memberi impak yang baik kepada penggunaan sumber yang lebih hijau serta mengurangkan kebergantungan produk berasaskan fosil hidupan. Produk yang terhasil terbukti mampu digunakan dalam pelbagai bidang contohnya bioperubatan dan pertanian. Ini secara tidak langsung memungkinkan eksploitasi bahan lignoselulosa daripada biojisim tanaman komersial di negara ini kepada kadar yang lebih maksimum.

\section{HIDROGEL}

Hidrogel merupakan jaringan tiga-dimensi (3D) yang mengandungi polimer hidrofilik yang sangat terhidrat. 
Ia diikat dengan ikatan kovalen atau memegang satu sama lain secara tarikan fizikal intramolekular atau intermolekul. Untuk membentuk hidrogel selulosa, selulosa yang terlarut boleh dipaut silang secara kimia (ikatan kovalen), paut silang fizikal atau gabungan keduaduanya (Buwalda et al. 2014). Hidrogel selulosa mampu menyerap air yang banyak mahupun cecair biologi, lebih beberapa ribu peratus daripada berat keringnya dan ia boleh membengkak secara terus tanpa melarut (ElSherbiny \& Yacoub 2013). Sifat hidrogel selulosa yang hidrofilik disebabkan oleh kehadiran kumpulan hidroksil yang berada di sepanjang tulang belakang rantai polimer selulosa (El-Sherbiny \& Yacoub 2013). Faktor interaksi yang mempengaruhi penyerapan air ke dalam hidrogel selulosa ialah secara kapilari, osmosis dan daya hidrat, yang diimbangi oleh daya kenyal yang dikenakan terhadap rantai paut silang polimer sewaktu proses pembengkakan (Buwalda et al. 2014). Secara kimianya, hidrogel selulosa mungkin stabil atau ia mungkin juga boleh terdegradasi, terurai, dan akhirnya larut di dalam pelarut (Hoffman 2012). Dalam keadaan bengkak, hidrogel selulosa menjadi lembut dan liat yang menyerupai tisu hidup. Antara semua teknologi biobahan, hidrogel selulosa merupakan polimer yang paling baik dalam menyerupai tisu biologi (Feksa et al. 2018).

Istilah hidrogel mula digunakan pada tahun 1894 yang merujuk kepada gel koloid yang diperbuat daripada garam tak organik (VanBemmelen 1894). Namun ia bukanlah hidrogel dari segi istilah. Kemudian, hidrogel yang sebenar dan dikenali dengan meluas pada hari ini adalah hasil laporan lebih 50 tahun yang lalu oleh Wichterle dan Lim (1960) yang menggunakan hidrogel berasaskan poli(2-hidroksietil metakrilat) untuk penghasilan kanta lekap. Daripada kajian ini, ia menjadi titik mula kepada perkembangan teknologi hidrogel terutamanya dalam masa dua dekad yang lalu. Hanya pada sekitar tahun 2010, penghasilan hidrogel pintar mula menjadi perhatian oleh pengkaji seluruh dunia (Buwalda et al. 2014). Bagi hidrogel pintar, strukturnya bergerak balas terhadap rangsangan luar seperti suhu, $\mathrm{pH}$, kepekatan ionik, cahaya, medan magnetik, medan elektrik dan kimia. Hidrogel pintar merubah struktur dan isi padunya sebagai gerak balas terhadap rangsangan luar dan ia sangat berguna untuk aplikasi teknologi termaju terutamanya dalam bidang bioperubatan dan pertanian.

Disebabkan sifat hidrogel selulosa yang bioserasi, ia kerap digunakan sebagai medium untuk aplikasi bioperubatan, seperti penghantaran ubat (Jeddi \& Mahkam 2019), tulang rawan artikular tiruan (Liu et al. 2020), kejuruteraan tisu (Maharjan et al. 2021) dan penyembuh luka (Capanema et al. 2018; Gou et al. 2020). Untuk mengekalkan persekitaran yang lembap, hidrogel selulosa juga boleh digunakan untuk merangsang angiogenisis, autolitik debridmen, dan neuroperlindungan. Secara relatif, hidrogel selulosa tercanggakan dan boleh disuai bentuk ke atas permukaan yang digunakan, ciri ini menjadikan ia sebagai pelindung mekopelekat yang baik (Feksa et al. 2018). Penggunaan hidrogel selulosa tidak terbatas dalam bidang bioperubatan sahaja, malahan sifat penahanan airnya membolehkan ia digunakan dalam bidang pertanian. Dalam kajian lepas, ia digunakan sebagai penyimpan atau pembekal air kepada tanaman (Calcagnile et al. 2019). Hidrogel yang dijana semula daripada selulosa juga mampu diolah sebagai baja pelepasan-perlahan dan baja pelepasan terkawal (Bortolin et al. 2013; Elbarbary \& Ghobashy 2017). Namun, penggunaan hidrogel selulosa sebagai medium alternatif kepada pembekal air yang konsisten pada tanaman perlu dikaji kesannya terhadap $\mathrm{pH}$ tanah, darjah degradasi dan kemampuan untuk kembang semula setelah air dijerap masuk ke dalam tanah (Abedi-Koupai et al. 2008; Demitri et al. 2013). Berdasarkan kajian lepas, penggunaan hidrogel terhadap tanaman juga tidak memberi kesan yang buruk kepada manusia (Feksa et al. 2018).

\section{PENGELASAN HIDROGEL}

Secara amnya, hidrogel dikelaskan kepada pelbagai jenis dan ia bergantung kepada sumber, ketahanan serta gerak balas rangsangan seperti yang ditunjukkan pada Rajah 5. Perbezaan yang wujud antara hidrogel tidak dapat dikenal pasti melalui fizikalnya, kerana secara fizikal, hidrogel wujud dalam keadaan yang serupa. Hidrogel yang terbentuk tidak semestinya jatuh di dalam satu kategori sahaja. Sebagai contoh, hidrogel selalunya boleh didegradasikan, konvensional terhadap gerak balas rangsangan, berkemungkinan ia bersifat neutral, struktur yang amorfus dan jika ia dibentuk menggunakan lebih daripada satu jenis monomer, maka komposisi hidrogelnya adalah dwikomponen.

\section{PEMBENGKAKAN HIDROGEL, MEKANISME RESAPAN AIR DAN FASA AIR DI DALAMNYA}

Hidrogel membengkak apabila ia direndam di dalam air atau pelarut namun ia tidak pula larut apabila air atau pelarut meresap masuk ke dalamnya. Pembengkakan berlaku atas faktor-faktor yang tertentu seperti ketumpatan jaringan hidrogel, sifat semula jadi pelarut, parameter interaksi polimer pelarut dan rangsangan gerak balas luar. Cecair yang pedap di dalam hidrogel bertindak sebagai penapis yang selektif yang membenarkan resapan molekul air atau pelarut, manakala jaringan polimer bertindak sebagai matriks yang memegang bersama dengan air atau pelarut (Hoffman 2012; Yahia et al. 2015). 


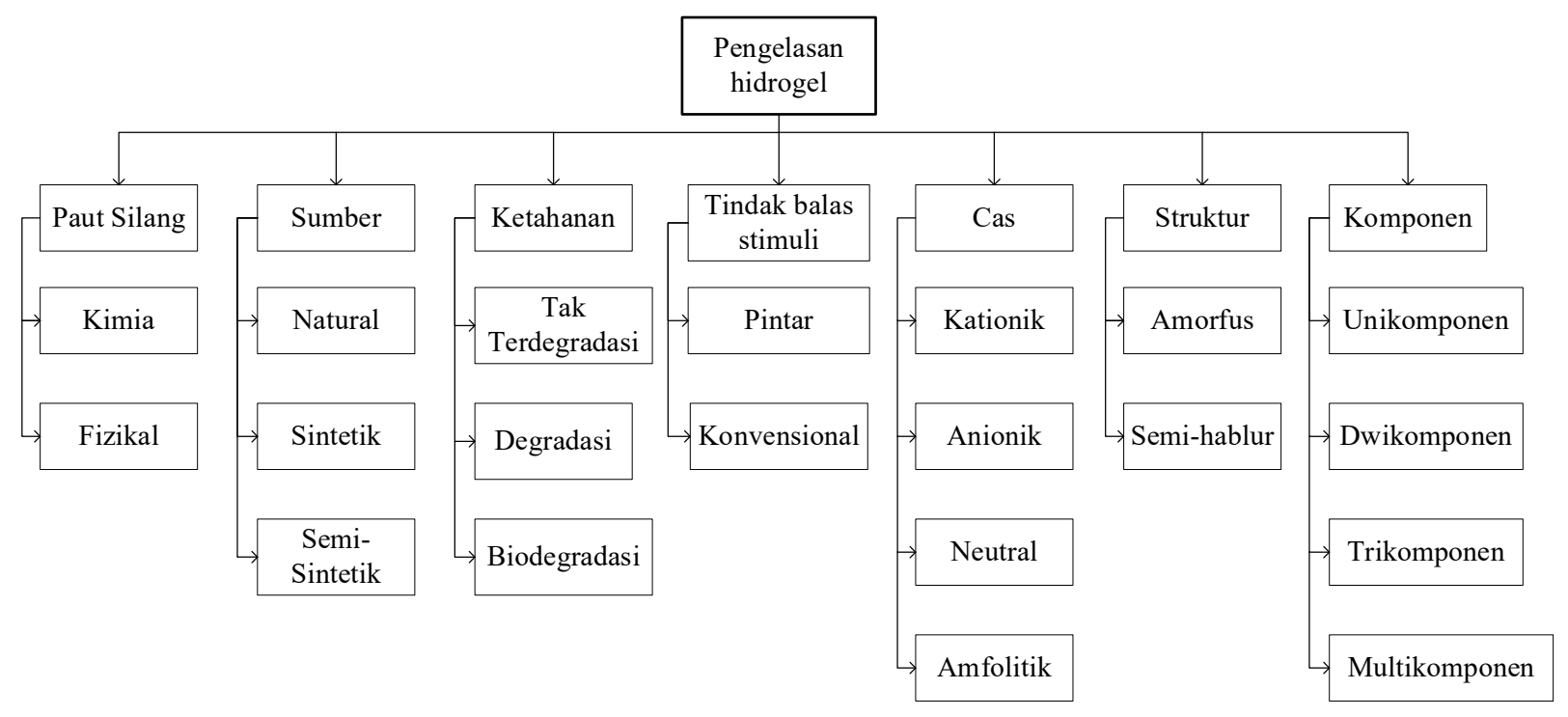

RAJAH 5. Pengelasan hidrogel

Ciri-ciri air di dalam hidrogel boleh menentukan penelapan nutrisi masuk ke dalam hidrogel dan produk bersel keluar daripada hidrogel. Apabila hidrogel yang kering mula menyerap air, air yang pertama masuk ke dalam struktur jaringan hidrogel akan membasahi kebanyakan kutub, seperti kumpulan hidrofilik yang terdapat pada tulang belakang polimer selulosa, yang membentuk air terikat primer. Apabila kumpulan berkutub ini basah, jaringan akan membengkak dan terbuka dan seterusnya mendedahkan kumpulan hidrofobik terhadap air. Kumpulan hidrofobik ini akan berinteraksi dengan molekul air atau pelarut, yang menyebabkan wujudnya air terikat secara hidrofobik atau dikenali sebagai air terikat sekunder. Air terikat primer dan sekunder selalunya digabungkan bersama dan dikenali sebagai air terikat total. Selepas bahagian berkutub (hidrofilik) dan hidrofobik berinteraksi dengan molekul air terikat, jaringan akan pedap air tambahan kerana daya penggerak rantai jaringan terhadap pelarutan tak terhingga. Penambahan air lebihan dihalang oleh paut silang kovalen (kimia) atau fizikal yang menyebabkan terbentuknya daya penarikbalikan jaringan kenyal. Dengan mekanisme ini, hidrogel mencapai tahap pembengkakan yang seimbang tanpa dilarutkan di dalam air atau pelarut (Salleh et al. 2019; Yahia et al. 2015).

Air pembengkakan tambahan yang pedap selepas kumpulan ionik, kutub dan hidrofobik menjadi tepu dengan air terikat dikenali sebagai air bebas atau air pukal.
Air bebas atau air pukal ini dianggap memenuhi ruang antara rantai jaringan, dan/atau kawasan tengah liang yang besar, makroliang atau lowong. Apabila jaringan membengkak, jika rantai jaringan atau paut silang terurai, hidrogel akan mula menyepai dan larut pada kadar yang bergantung pada komposisi hidrogel itu sendiri (Salleh et al. 2019; Yahia et al. 2015).

\section{PENGERINGAN HIDROGEL}

Proses pengeringan hidrogel yang berbeza bukan sahaja akan memberi kesan kepada struktur produk yang terhasil malahan penamaan produk juga akan berbeza. Pengeringan hidrogel secara konvensional iaitu penyejatan akan menyebabkan struktur hidrogel musnah yang akan membentuk xerogel. Namun, apabila hidrogel dikeringkan menggunakan kaedah pengeringan genting lampau, hidrogel akan mengekalkan struktur tulangnya yang membentuk aerogel. Contoh produk lain hasil daripada pengeringan hidrogel secara pengeringan beku membentuk hidrogel kering yang dikenali sebagai kriogel selulosa. Dari segi fizikal dan beratnya, ia menyerupai aerogel namun disebabkan hidrogel disejukbekukan terlebih dahulu diikuti dengan proses penarikan ketulan ais secara vakum, penamaan produk hidrogel turut berubah. Proses dan teknik pengeringan hidrogel akan menentukan sama ada produk yang dijana semula itu mempunyai keliangan yang tinggi atau ketumpatan yang tinggi atau sebaliknya. 


\section{AEROGEL}

Berdasarkan terminologi yang diberikan oleh IUPAC (McNaught \& Wilkinson 1997), aerogel merupakan gel yang mengandungi pepejal mikroliang dengan fasa serakannya ialah gas. Aerogel pertama kali dilaporkan pada tahun 1932 oleh Kistler. Berdasarkan kajian beliau, untuk mengekalkan struktur tulang hidrogel dan mengurangkan kesan pengecutan sewaktu pengeringan, cecair di dalam hidrogel perlu dibuang menggunakan keadaan genting lampau. Teknik pengeringan genting lampau dimulai dengan hidrogel yang mengandungi air dibilas menggunakan aseton. Kemudian, aseton dibilas keluar daripada hidrogel dengan cecair $\mathrm{CO}_{2}$ bertekanan tinggi. Secara praktisnya, pengeringan genting lampau melibatkan pemanasan hidrogel di dalam autoklaf sehingga tekanan dan suhu melebihi suhu genting $\left(\mathrm{S}_{\mathrm{k}}\right)$ dan tekanan genting $\left(\mathrm{T}_{\mathrm{k}}\right)$ cecair yang terperangkap di dalam hidrogel. Prosedur yang digunakan ini adalah untuk menghalang pembentukan meniskus cecairwap pada penutup liang (daya rerambut sifar), yang memberi tegangan mekanikal cecair dan tekanan pada dinding liang, yang menyebabkan pengecutan hidrogel. Kemudian, cecair genting lampau dibebaskan secara perlahan-lahan sebagai gas, dan akhirnya membentuk 'tulang pepejal kering' daripada hidrogel yang basah. Tulang pepejal kering inilah yang dikenali sebagai aerogel. Sampel kering yang terbentuk ini mempunyai tekstur liang yang sangat terbuka, menyerupai struktur liang yang ada sewaktu ia di dalam keadaan basah iaitu hidrogel (Pierre 2011; Tamon et al. 2001).

Secara relatif, aerogel mempunyai isi padu liang spesifik yang sangat tinggi walaupun pembentukan liang ini mungkin berbeza-beza bergantung dengan sifat semula jadi pepejal yang digunakan (Pierre 2011). Umumnya, sifat fizikal aerogel sering dikaitkan dengan berat dan ketumpatan yang sangat rendah, tinggi luas permukaan. Aerogel boleh diperoleh dalam pelbagai bentuk dan saiz dan ia bergantung sepenuhnya kepada proses pembentukan hidrogel. Silika merupakan bahan yang paling kerap digunakan dalam kelas bahan kimia tak organik untuk proses pembentukan aerogel. Aerogel silika mempunyai struktur nanoliang (keliangan90-99.8\%), ketumpatan yang rendah $\left(\sim 0.003 \mathrm{~g} / \mathrm{cm}^{3}\right)$ serta luas permukaan spesifik yang tinggi $\left(500-1200 \mathrm{~m}^{2} / \mathrm{g}\right.$ ) (Stergar \& Maver 2016). Pengelasan hidrogel dibahagikan seperti pada Rajah 6.

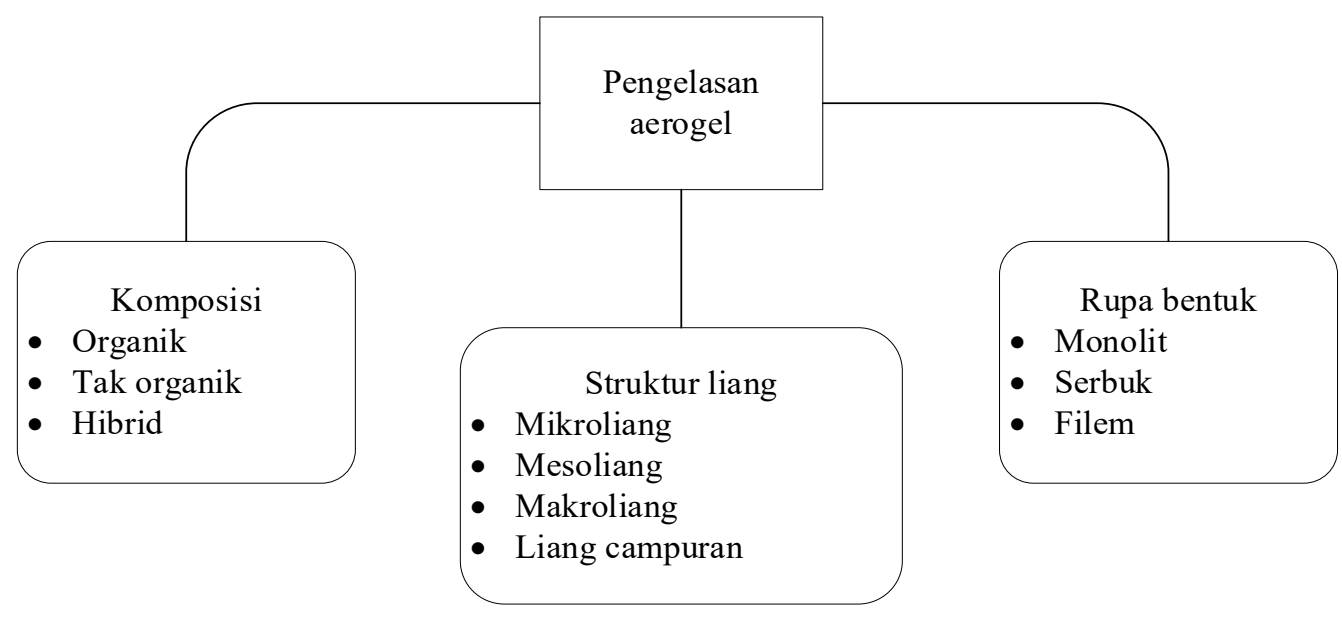

RAJAH 6. Pengelasan aerogel

Berdasarkan pengelasan aerogel, komposisi bahan yang digunakan merupakan titik mula kepada pembentukan aerogel yang memberinya sifat yang pelbagai. Namun, komposisi organik paling menarik perhatian para pengkaji terutamanya penggunaan bahan lignoselulosa daripada biojisim tanaman. Contohnya penggunaan selulosa sebagai bahan asas kepada pembinaan struktur tulang aerogel tidak kurang menariknya jika dibandingkan dengan bahan tak organik. Proses pelarutan selulosa I kepada selulosa II dan diikuti dengan proses penjanaan semula kepada hidrogel serta pengeringan supergenting membentuk bahan seakan aerogel yang dikenali sebagai aeroselulosa (Innerlohinger et al. 2006). Aeroselulosa yang terhasil mempunyai taburan saiz liang yang luas, daripada puluhan nanometer kepada ratusan mikrometer serta luas permukaan yang 
ratusan $\mathrm{m}^{2} / \mathrm{g}$. Ketumpatan aeroselulosa meningkat apabila semakin tinggi kepekatan bahan selulosa yang digunakan (Innerlohinger et al. 2006; Sescousse et al. 2011). Natijahnya, penghasilan aeroselulosa sangat bergantung kepada jenis selulosa yang digunakan, berat molekul, darjah pempolimeran, jenis pelarut, jenis agen paut silang serta cecair yang digunakan semasa proses pembengkakan hidrogel. Sumber selulosa yang tidak terhad menjadikan ia sebagai bahan hijau semula jadi yang sesuai untuk kepelbagaian aplikasi terutamanya produk terbiodegradasi. Dalam kajian sebelum ini, aeroselulosa yang terhasil daripada proses pelarutan yang menggunakan larutan $\mathrm{NaOH}$ mempunyai keliangan yang tinggi $(>95 \%)$ dan ketumpatan yang rendah $(\sim 0.1$ $\mathrm{g} / \mathrm{cm}^{3}$ ) (Gavillon \& Budtova 2007).

Perlu ditegaskan, pengeringan hidrogel secara genting lampau merupakan proses yang paling kritikal sewaktu penjanaan aerogel. Pengeringan yang tidak sempurna menyebabkan pengecutan yang tinggi yang akhirnya meningkatkan ketumpatan aerogel serta luas permukaannya berkurang (Innerlohinger et al. 2006). Walaupun aerogel telah lama dikenali, namun potensinya masih lagi tidak digunakan sepenuhnya. Antara aplikasi produk aerogel yang dihasilkan daripada selulosa ialah sebagai bahan erap minyak boleh guna semula (Lin et al. 2015), penghantar ubat untuk rawatan kanser (Wang et al. 2017), penjanaan semula kulit (Khan et al. 2018), tapak pelekatan sel (Mirtaghavi et al. 2020), pemisah air/ minyak yang efektif (Liao et al. 2016).

\section{KRIOGEL}

Hidrogel yang dikeringkan dengan kaedah pengeringan beku dikenali sebagai kriogel. Hingga kini, tiada pengenalan istilah baharu untuk kriogel yang berasaskan hidrogel selulosa. Objektif teknik pengeringan beku serupa dengan pengeringan genting lampau iaitu mengekalkan struktur tulang hidrogel yang basah dalam keadaan tulang pepejal kering. Perkataan kriogel sebenarnya dibina daripada dua perkataan yang berbeza iaitu 'krio' dan 'gel'. Krio pula berasal daripada perkataan Yunani iaitu 'kruos' yang bermaksud beku (Kumar 2016).

Secara relatif, kriogel mempunyai ketumpatan yang lebih tinggi, luas permukaan yang lebih rendah, isi padu mesoliang yang lebih kecil, pengecutan struktur tulang hidrogel yang lebih besar jika dibandingkan dengan aerogel (Tamon \& Ishizaka 1999). Berdasarkan kajian lepas oleh Salleh et al. (2020), yang mengkaji perbezaan sifat aerogel dan kriogel dengan menggunakan sumber bahan mentah yang sama iaitu selulosa, didapati ciri-ciri tekstur dan struktur kriogel menyerupai aerogel begitu juga dengan komposisi kimianya. Namun, kriogel mempunyai jumlah isi padu liang serta luas permukaannya lebih rendah berbanding dengan aerogel.

Meskipun begitu, kebaikan pengeringan beku berbanding dengan pengeringan genting lampau ialah kos efektif serta teknik pengeringan yang lebih mudah. Pengeringan beku juga dikenali sebagai liofilisasi atau pengeringan krio. Untuk menghasilkan kriogel, terdapat dua langkah asas yang perlu dipatuhi iaitu: Hidrogel dibekukan terlebih dahulu diikuti dengan pemejalwapan cecair atau pelarut beku di dalam hidrogel (Klvana et al. 1989). Selain itu, proses pembekuan yang berbeza (contoh: pembekuan homogen dan pembekuan searah) juga boleh digunakan untuk memberikan hasil produk yang berbeza. Didapati, pembekuan searah memberikan hasil yang lebih baik dengan pengecutan isi padu yang lebih rendah berbanding dengan pembekuan homogen (Buchtová \& Budtova 2016). Rajah 7 menunjukkan visual proses pengeringan beku terhadap hidrogel selulosa yang menghasilkan kriogel. Dua langkah asas seperti yang dinyatakan sebelum ini membantu pembentukan kriogel. Proses pembekuan sampel hidrogel merupakan proses yang penting sebelum pembentukan kriogel. Pembekuan yang perlahan menghasilkan hablur besar yang lebih teratur manakala pembekuan pantas menghasilkan hablur kecil yang kurang teratur. Pembentukan struktur tulang kriogel bukan sahaja dipengaruhi oleh kuantiti air di dalam hidrogel tetapi dipengaruhi juga oleh kadar pembekuan. Semakin perlahan kadar pembekuan, semakin besar saiz hablur dan semakin mudah ia merosakkan struktur dinding kriogel (Gun'ko et al. 2013).

Antara sifat tipikal yang terdapat pada tekstur dan struktur kriogel ialah pembentukan liang antara hubung serta liang yang memenuhi antara dinding kriogel (Kumar et al. 2010). Pembentukan liang antara hubung ini berlaku kerana air yang dibekukan membentuk hablur di antara dinding kriogel. Ketika proses pengeringan beku, pemejalwapan cecair beku secara vakum menyebabkan dinding kriogel membentuk liang antara hubung. Selain itu, kriogel yang terbentuk juga mempunyai matriks makroliang lampau (Salleh et al. 2020). Saiz liang ini boleh diolah bergantung dengan sumber bahan mentah, berat molekul, darjah pempolimeran, jenis pelarut dan jenis agen paut silang sewaktu pembentukan hidrogel (Salleh et al. 2020). Liang yang terbentuk mempunyai julat sekitar ratusan mikron (Kumar 2016). Klasifikasi saiz liang kriogel yang lebih spesifik telah digariskan oleh Gun'ko et al. (2013) iaitu nanoliang sempit (diameter $0.4<\mathrm{d}<2 \mathrm{~nm})$, tengah $(2<$ $\mathrm{d}<50 \mathrm{~nm})$ dan lebar $(50<\mathrm{d}<100 \mathrm{~nm})$, mikroliang (100 


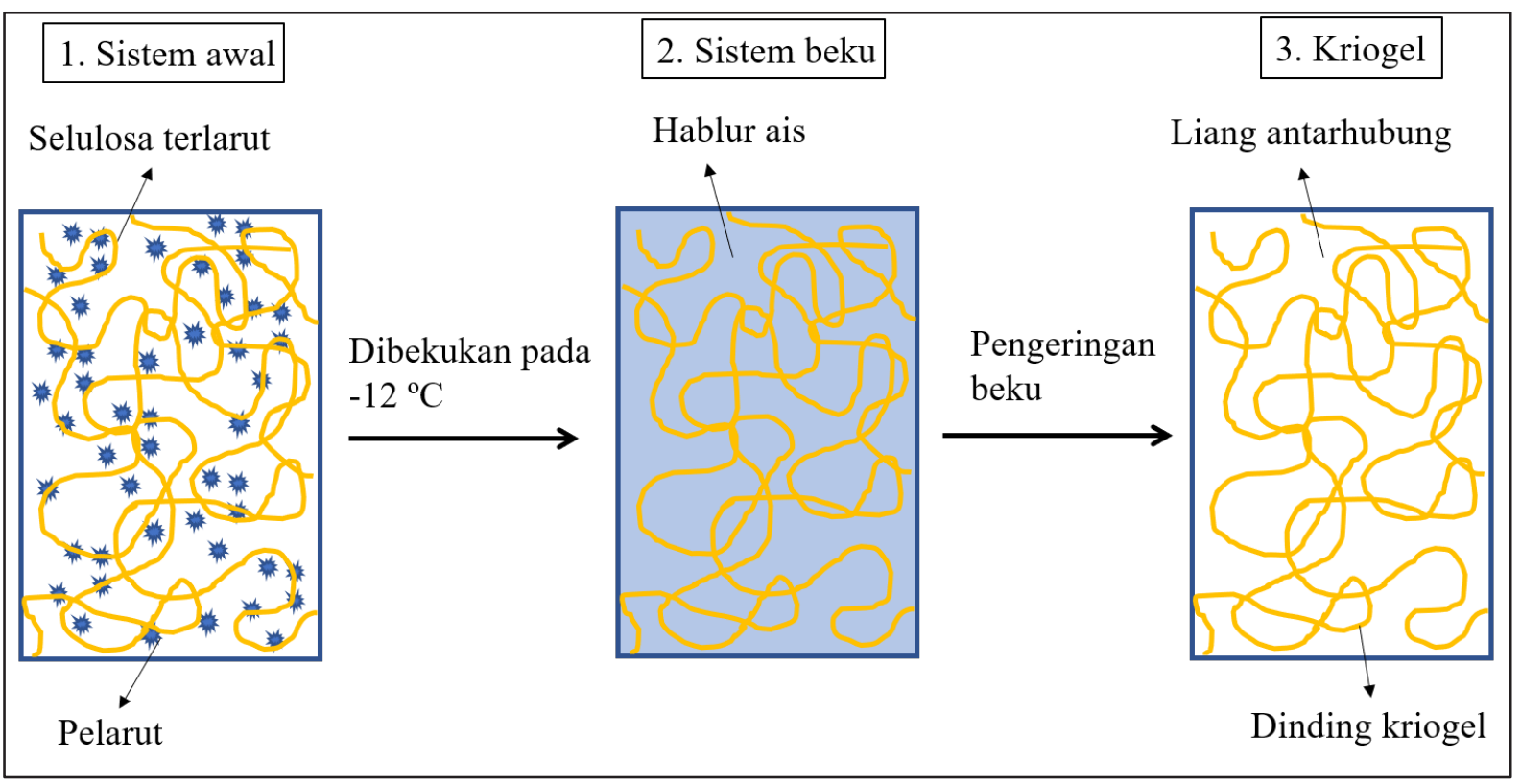

RAJAH 7. Proses pengeringan beku untuk penjanaan kriogel

$\mathrm{nm}<\mathrm{d}<100 \mu \mathrm{m})$ dan makroliang $(\mathrm{d}>100 \mu \mathrm{m})$. Untuk kriogel yang berasaskan selulosa, pembetukan saiz liang cenderung kepada saiz yang lebih besar $(\mathrm{d}>100 \mu \mathrm{m})$ kerana kewujudan kumpulan hidrofilik pada struktur tulang belakang polimernya membolehkan ia memegang air pada kuantiti yang banyak pada matriks hidrogelnya. Akibatnya, gangguan sewaktu penghabluran air kepada ais kepada struktur dinding selulosa membentuk struktur liang antara hubung yang lebih besar serta berlakunya penipisan kepada dinding selulosa kriogel. Fenomena penipisan dinding kriogel selulosa ini dilaporkan oleh Salleh et al. (2020) dengan daya tolakan air sewaktu pembengkakan yang terlampau kepada dinding selulosa menyebabkan penipisan sehingga ke saiz nano iaitu 22.33 nm. Salleh et al. (2020) juga mendapati kriogel yang berasaskan selulosa mempunyai tekstur yang lembut, berwarna putih, serta pengecutan yang ketara selepas proses pengeringan beku ke atas kriogel daripada saiz asalnya iaitu hidrogel. Ini membuktikan pengeringan beku tidak dapat mengekalkan struktur tulang hidrogel berbanding dengan pengeringan genting lampau yang membentuk aerogel.

Penggunaan kriogel dalam pelbagai aplikasi bahan sudah lama dipraktikkan. Disebabkan ia mempunyai liang antara hubung yang besar pada dindingnya, ia mempunyai kemampuan resapan yang sangat baik. Kebanyakan kriogel hanya mengambil masa beberapa minit sahaja untuk mencapai kapasiti pembengkakan maksimum (Kumar 2016). Sama seperti aerogel, kriogel berasaskan selulosa juga banyak digunakan untuk penghasilan produk bio-perubatan serta kejuruteraan tisu (Hixon et al. 2017).

\section{XEROGEL}

IUPAC (1997) mendefinisikan xerogel sebagai jaringan terbuka yang terbentuk dengan penyingkiran semua agen pembengkakan hidrogel. Hingga kini, tiada pengenalan istilah baharu untuk xerogel yang berasaskan hidrogel selulosa. Secara amnya, hidrogel yang strukturnya musnah setelah ia dikeringkan secara penyejatan dikenali sebagai xerogel (Tamon et al. 1997). Maka, untuk sebarang jenis pengeringan yang dikenakan ke atas hidrogel, apabila struktur tulang hidrogel itu musnah, produk yang terjana dikenali sebagai xerogel. Pengeringan konvensional mahupun pengeringan yang tidak sempurna terhadap hidrogel memusnahkan struktur tulangnya adalah disebabkan kegagalan proses penyejatan menghalang pembentukan daya rerambut yang kuat. Daya rerambut ini merupakan meniskus cecairwap yang terbentuk di dalam hidrogel yang menarik dinding di dalam jaringan struktur tulang hidrogel basah. Maka, disebabkan daya rerambut yang kuat, sewaktu pengeringan, isi padu air di dalam hidrogel yang semakin berkurangan meningkatkan lagi daya rerambut ini. Seterusnya menyebabkan struktur tulang hidrogel 
yang basah mendekati satu sama lain dan memusnahkan struktur tulang hidrogel. Jika dibandingkan dengan aerogel mahupun kriogel, teknik pengeringan yang baik akan memberi daya rerambut sifar yang akan membentuk struktur tulang kering yang rendah ketumpatannya (Błaszczyński et al. 2013).

Xerogel juga dikenali sebagai jaringan polimer tanpa air. Kapasiti xerogel memegang air bergantung dengan jumlah kumpulan hidrofilik pada struktur tulangnya serta ketumpatan paut silang bahan. Semakin banyak jumlah kumpulan hidrofilik, semakin tinggi kemampuannya memegang air. Semakin tinggi ketumpatan paut silang, berlaku peningkatan sifat hidrofobik yang menyebabkan kemampuan struktur tulangnya meregang berkurang, maka kemampuannya untuk memegang air semakin rendah (Pal et al. 2009). Xerogel selalunya mempunyai keliangan yang agak rendah $(25 \%)$, luas permukaan (150-900 $\left.\mathrm{m}^{2} / \mathrm{g}\right)$ serta saiz liang yang kecil (1-10 nm) (Gulrez et al. 2003). Jika hidrogel yang dikeringkan secara penyejatan gagal mengekalkan keliangan pada $15-50 \%$, tidak mempunyai liang bersaiz nano dan luas permukaan yang lebih daripada $1000 \mathrm{~m}^{2} / \mathrm{g}$, maka ia tidak boleh diklasifikasikan sebagai xerogel (Buchtová \& Budtova 2016). Terdapat juga kajian lepas yang menunjukkan xerogel kering-ketuhar mempunyai pengekalan air yang tinggi serta kestabilan koloid yang lebih baik berbanding kriogel (Beaumont et al. 2017). Untuk xerogel berasaskan selulosa, kajian terhadapnya masih lagi tidak meluas jika dibandingkan dengan aerogel dan kriogel. Namun, potensi serta penggunaannya dipelbagaikan dengan kajian yang dijalankan oleh Yamasaki et al. (2019). Mereka dapati xerogel berasaskan nanoselulosa yang disediakan secara pengeringan penyejatan pada suhu ambien mempunyai peratusan keliangan yang tinggi (71-76\%) yang setanding dengan aeroselulosa berasaskan nanoselulosa. Meskipuan keliangan xerogel selulosa kajian Yamasaki et al. (2019) melebihi daripada julat yang digariskan oleh Buchtová dan Budtova (2016) dan Gulrez et al. (2003), secara definisinya ia masih dianggap sebagai xerogel. Antara konsep asas yang digunakan dalam kajian Yamasaki et al. (2019) untuk mendapat xerogel selulosa yang setanding dengan aeroselulosa ialah penguatan struktur hidrogel secara ikatan ionik untuk membolehkan struktur dinding selulosa mampu menahan daya rerambut yang kuat sewaktu penyejatan. Seterusnya menghasilkan xerogel yang mempunyai peratusan keliangan yang setanding dengan aeroselulosa dan kriogel. Xerogel monolitik yang dihasilkan juga mempunyai permukaan yang kasar, bentuk yang herot serta legap meskipun mempunyai keliangan yang tinggi (Yamasaki et al. 2019).
Kajian mengenai xerogel kurang jika dibandingkan dengan aerogel dan kriogel. Ini kerana, kebanyakan penyelidik memfokuskan tentang kemampuan bahan pepejal untuk dijana kepada struktur tulang yang kekal, ketumpatan yang rendah dan luas permukaan yang tinggi. Apabila struktur tulang hidrogel musnah sewaktu pengeringan, maka pengecutan yang sangat ketara akan berlaku, isi padu akan berkurang maka ketumpatannya meningkat dan luas permukaan yang rendah jika dibandingkan dengan aerogel dan kriogel. Namun, terdapat kajian yang menunjukkan xerogel berasaskan selulosa sesuai digunakan sebagai tempat penyimpanan nutrien dan/atau farmasi tumbuhan (Sannino et al. 2009), penyimpan dielektrik dan elektrokimia (Pottathara et al. 2018) dan substrat kepada pengesan gas ammonia (Khattab et al. 2019).

\section{KESIMPULAN}

Struktur molekul selulosa yang berhablur serta kekuatan ikatan hidrogen bukanlah faktor utama yang mempengaruhi keterlarutan selulosa namun sifat amfifiliknya serta interaksi bahagian hidrofobik selulosa. Maka penggunaan pelarut yang bersesuaian adalah perlu mengikut keperluan penyelidikan dan objektif produk yang ingin dihasilkan. Jika sifat kimia selulosa ingin dikekalkan maka pelarut tak-terbitan boleh digunakan dan jika pengubahsuaian kimia diperlukan maka pelarut terbitan lebih sesuai digunakan. Bagi pelarut tak-terbitan, proses pelarutan merupakan proses yang sangat kompleks dan setiap faktor yang mempengaruhi perlu diambil kira. Keterlarutan selulosa boleh dipertingkatkan jika larutan yang digunakan juga bersifat amfifilik serta kehadiran cosolute yang mampu melemahkan interaksi hidrofobik pada gegelang glukosa selulosa. Bagi pelarut terbitan pula, pelarut yang digunakan mestilah mampu mengaruhkan pengubahsuaian kovalen pada tulang belakang selulosa dan kumpulan berfungsi yang diperkenalkan pada selulosa mestilah mudah dilepaskan. Selulosa yang terlarut mempunyai kefungsian yang lebih baik dalam bidang yang pelbagai serta mampu menyaingi polimer sintetik dalam terknologi termaju. Antara produk yang boleh dijana semula bagi selulosa yang terlarut ialah hidrogel, aerogel, kriogel dan xerogel.

\section{PENGHARGAAN}

Setinggi-tinggi penghargaan diberikan kepada Kementerian Pengajian Tinggi (KPT), Malaysia untuk Geran Penyelidikan LRGS/1/2019/UKM-UKM/5/1. Tidak lupa juga Pusat Pengurusan Penyelidikan \& Instrumentasi 
(CRIM), Universiti Kebangsaan Malaysia untuk Geran Penyelidikan MI-2020-006.

\section{RUJUKAN}

Abedi-Koupai, J., Sohrab, F. \& Swarbrick, G. 2008. Evaluation of hydrogel application on soil water retention characteristics. J. Plant Nutr. 31: 317-331.

Atalla, R.H. \& Isogai, A. 2010. Celluloses. In Comprehensive Natural Products II: Chemistry and Biology, edited by Mander, L. \& Liu, H.W. Elsevier. pp. 493-539.

Beaumont, M., König, J., Opietnik, M., Potthast, A. \& Rosenau, T. 2017. Drying of a cellulose II gel: Effect of physical modification and redispersibility in water. Cellulose 24: 1199-1209.

Błaszczyński, T., Ślosarczyk, A. \& Morawski, M. 2013. Synthesis of silica aerogel by supercritical drying method. Procedia Eng. 57: 200-206.

Bortolin, A., Aouada, F.A., Mattoso, L.H.C. \& Ribeiro, C. 2013. Nanocomposite PAAm/methyl cellulose/montmorillonite hydrogel: Evidence of synergistic effects for the slow release of fertilizers. J. Agric. Food Chem. 61: 7431-7439.

Buchtová, N. \& Budtova, T. 2016. Cellulose aero-, cryo- and xerogels: Towards understanding of morphology control. Cellulose 23: 2585-2595.

Buwalda, S.J., Boere, K.W.M., Dijkstra, P.J., Feijen, J., Vermonden, T. \& Hennink, W.E. 2014. Hydrogels in a historical perspective: From simple networks to smart materials. J. Control Release 190: 254-273.

Cai, J. \& Zhang, L. 2005. Rapid dissolution of cellulose in LiOH/ urea and $\mathrm{NaOH} /$ urea aqueous solutions. Macromol. Biosci. 5: 539-548.

Cai, J., Zhang, L., Liu, S., Liu, Y., Xu, X., Chen, X., Chu, B., Guo, X., Xu, J., Cheng, H., Han, C.C. \& Kuga, S. 2008. Dynamic self-assembly induced rapid dissolution of cellulose at low temperatures. Macromolecules 41: 9345-9351.

Calcagnile, P., Sibillano, T., Giannini, C., Sannino, A. \& Demitri, C. 2019. Biodegradable poly (lactic acid)/cellulose-based superabsorbent hydrogel composite material as water and fertilizer reservoir in agricultural applications. J. Appl. Polym. Sci. 136(21): 47546

Capanema, N.S.V., Mansur, A.A.P., Jesus, A.C.D., Carvalho, S.M., De Oliveira, L.C. \& Mansur, H.S. 2018. Superabsorbent crosslinked carboxymethyl cellulose-PEG hydrogels for potential wound dressing applications. Int. J. Biol. Macromol. 106: 1218-1234.

Cuissinat, C. \& Navard, P. 2008. Swelling and dissolution of cellulose, Part III: Plant fibres in aqueous systems. Cellulose 15: 67-74.

Cuissinat, C. \& Navard, P. 2006. Swelling and dissolution of cellulose Part II : Free floating cotton and wood fibres in $\mathrm{NaOH}$ - water - additives systems. Macromol. Symp. 244: 19-30.

Cuissinat, C., Navard, P. \& Heinze, T. 2008a. Swelling and dissolution of cellulose. Part IV: Free floating cotton and wood fibres in ionic liquids. Carbohydr. Polym. 72: 590596.
Cuissinat, C., Navard, P. \& Heinze, T. 2008b. Swelling and dissolution of cellulose, Part V: Cellulose derivatives fibres in aqueous systems and ionic liquids. Cellulose 15: 75-80.

Davidson, G.F. 1934. 12 - The dissolution of chemically modified cotton cellulose in alkaline solutions: Part I - In solutions of sodium hydroxide, particularly at temperatures below the normal. J. Text. Inst. Trans. 25: T174-T196.

Davis, W.E., King, A.J., Barry, A.J. \& Peterson, F.C. 1943. X-ray studies of reactions of cellulose in non-aqueous systems. II. Interaction of cellulose and primary amines. J. Am. Chem. Soc. 65: 1294-1299.

De Silva, R., Vongsanga, K., Wang, X. \& Byrne, N. 2016. Understanding key wet spinning parameters in an ionic liquid spun regenerated cellulosic fibre. Cellulose 23: 27412751.

Delbecq, F., Wang, Y., Muralidhara, A., El Ouardi, K.E., Marlair, G. \& Len, C. 2018. Hydrolysis of hemicellulose and derivatives - A review of recent advances in the production of furfural. Front. Chem. 6: 146.

Demitri, C., Scalera, F., Madaghiele, M., Sannino, A. \& Maffezzoli, A. 2013. Potential of cellulose-based superabsorbent hydrogels as water reservoir in agriculture. Int. J. Polym. Sci. 2013: 435073.

El-Sherbiny, I. \& Yacoub, M. 2013. Hydrogel scaffolds for tissue engineering: Progress and challenges. Glob. Cardiol. Sci. Pract. 2013: 316-342.

El Seoud, O.A. \& Heinze, T. 2005. Organic esters of cellulose: New perspectives for old polymers. Adv. Polym. Sci. 186: 103-149.

Elbarbary, A.M. \& Ghobashy, M.M. 2017. Controlled release fertilizers using superabsorbent hydrogel prepared by gamma radiation. Radiochim. Acta 105: 865-876.

Feksa, L.R., Troian, E.A., Muller, C.D., Viegas, F., Machado, A.B. \& Rech, V.C. 2018. Hydrogels for biomedical applications. In Nanostructures for the Engineering of Cells, Tissues and Organs: From Design to Applications, edited by Grumezescu, A.M. William Andrew Publishing. pp. 403-438.

Gan, S., Zakaria, S., Salleh, K.M., Anuar, N.I.S., Moosavi, S. \& Chen, R.S. 2020. An improved physico-mechanical performance of macropores membrane made from synthesized cellulose carbamate. Int. J. Biol. Macromol. 158: 552-561.

Gavillon, R. \& Budtova, T. 2007. Aerocellulose: New highly porous cellulose prepared from cellulose- $\mathrm{NaOH}$ aqueous solutions. Biomacromolecules 9: 269-277.

Glasser, W.G. 2008. Cellulose and associated heteropolysaccharides. Glycoscience. Berlin, Heidelberg: Springer-Verlag. p. 1473.

van de ven, T.G.M. \& Godbout, L. 2013. Cellulose - Fundamental Aspects. https://www.intechopen.com/books/2326.

Gou, L., Xiang, M. \& Ni, X. 2020. Development of wound therapy in nursing care of infants by using injectable gelatin-cellulose composite hydrogel incorporated with silver nanoparticles. Mater. Lett. 277: 128340.

Graenacher, C. 1934. Cellulose Solution. US1943176A. 
Gulrez, S.K.H., Al-Assaf, S. \& Phillips, G.O. 2003. Hydrogels: Methods of preparation, characterisation and applications. Prog. Mol. Environ. Bioeng. 51: 117-150.

Gun'ko, V.M., Savina, I.N. \& Mikhalovsky, S.V. 2013. Cryogels: Morphological, structural and adsorption characterisation. Adv. Colloid Interface Sci. 187-188: 1-46.

Guo, Y., Zhou, J., Wang, Y., Zhang, L. \& Lin, X. 2010. An efficient transformation of cellulose into cellulose carbamates assisted by microwave irradiation. Cellulose 17: 11151125.

Heinze, T. \& Koschella, A. 2005. Solvents applied in the field of cellulose chemistry: A mini review. Polímeros 15: 84-90.

Hixon, K.R., Lu, T. \& Sell, S.A. 2017. A comprehensive review of cryogels and their roles in tissue engineering applications. Acta Biomater. 62: 29-41.

Hoffman, A.S. 2012. Hydrogels for biomedical applications. Adv. Drug Deliv. Rev. 64: 18-23.

Innerlohinger, J., Weber, H.K. \& Kraft, G. 2006. Aerocellulose: Aerogels and aerogel-like materials made from cellulose. Macromol. Symp. 244: 126-135.

Itagaki, H., Tokai, M. \& Kondo, T. 1997. Physical gelation process for cellulose whose hydroxyl groups are regioselectively substituted by fluorescent groups. Polymer (Guildf). 38: 4201-4205.

McNaught, A.D. \& Wilkinson, A. 1997. Coprecipitation. Compendium of Chemical Terminology: IUPAC Recommendations. 2nd ed. Blackwell Science. p. 336.

Jeddi, M.K. \& Mahkam, M. 2019. Magnetic nano carboxymethyl cellulose-alginate/chitosan hydrogel beads as biodegradable devices for controlled drug delivery. Int. $J$. Biol. Macromol. 135: 829-838.

Karadagli, I., Milow, B., Ratke, L. \& Schulz, B. 2012. Synthesis and characterization of highly porous cellulose aerogels for textiles applications. https://elib.dlr.de/78416/.

Khan, S., Ul-islam, M., Ikram, M., Ul, S., Wajid, M., Israr, M., Hyun, J., Yoon, S. \& Kon, J. 2018. Preparation and structural characterization of surface modified microporous bacterial cellulose scaffolds: A potential material for skin regeneration applications in vitro and in vivo. Int. J. Biol. Macromol. 117: 1200-1210.

Khattab, T.A., Dacrory, S., Abou-Yousef, H. \& Kamel, S. 2019. Development of microporous cellulose-based smart xerogel reversible sensor via freeze drying for naked-eye detection of ammonia gas. Carbohydr. Polym. 210: 196-203.

Kihlman, M., Medronho, B.F., Romano, A.L., Germgård, U. \& Lindman, B. 2013. Cellulose dissolution in an alkali based solvent: Influence of additives and pretreatments. J. Braz. Chem. Soc. 24: 295-303.

Kistler, S.S. 1932. Coherent expanded aerogels. J. Phys. Chem. 63: 52-64.

Klemm, D., Philipp, B., Heinze, T., Heinze, U. \& Wagenknecht, W. 1998. Comprehensive Cellulose Chemistry: Fundamentals and Analytical Methods, Volume 1. Wiley-VCH Verlag $\mathrm{GmbH}$.

Klvana, D., Chaouki, J., Repellin-Lacroix, M. \& Pajonk, G. 1989. A new method of preparation of aerogel-like materials using a freeze-drying process. Le J. Phys. Colloq. 50(C4): C4-29-C4-32.

Kondo, T. 1997. The relationship between intramolecular hydrogen bonds and certain physical properties of regioselectively substituted cellulose derivatives. J. Polym. Sci. Part B Polym. Phys. 35: 717-723.

Kono, H. \& Fujita, S. 2012. Biodegradable superabsorbent hydrogels derived from cellulose by esterification crosslinking with 1,2,3,4-butanetetracarboxylic dianhydride. Carbohydr. Polym. 87: 2582-2588.

Kumar, A. 2016. Supermacroporous Cryogels: Biomedical and Biotechnological Applications. New Jersey: CRC Press.

Kumar, A., Mishra, R., Reinwald, Y. \& Bhat, S. 2010. Cryogels: Freezing unveiled by thawing. Mater. Today 13: 42-44.

Labafzadeh, S.R. 2015. Cellulose-based materials. Academic Dissertation. University of Helsinki (Unpublished).

Leipner, H., Fischer, S., Brendler, E. \& Voigt, W. 2000. Structural changes of cellulose dissolved in molten salt hydrates. Macromol. Chem. Phys. 201: 2041-2049.

Liao, Q., Su, X., Zhu, W., Hua, W., Qian, Z., Liu, L. \& Yao, J. 2016. Flexible and durable cellulose aerogels for highly effective oil/water separation. RSC Adv. 6: 63773-63781.

Lin, R., Li, A., Zheng, T., Lu, L. \& Cao, Y. 2015. Hydrophobic and flexible cellulose aerogel as an efficient, green and reusable oil sorbent. RSC Adv. 5: 82027-82033.

Lindman, B., Karlström, G. \& Stigsson, L. 2010. On the mechanism of dissolution of cellulose. J. Mol. Liq. 156: 76-81.

Liu, Q., Liu, J., Qin, S., Pei, Y., Zheng, X. \& Tang, K. 2020. High mechanical strength gelatin composite hydrogels reinforced by cellulose nanofibrils with unique beadson-a-string morphology. Int. J. Biol. Macromol. 164: $1776-1784$

Lue, A., Liu, Y., Zhang, L. \& Potthas, A. 2011. Light scattering study on the dynamic behaviour of cellulose inclusion complex in LiOH/urea aqueous solution. Polymer (Guildf). 52: 3857-3864.

Luo, X. \& Zhang, L. 2013. New solvents and functional materials prepared from cellulose solutions in alkali/urea aqueous system. Food Res. Int. 52: 387-400.

Maharjan, B., Park, J., Kaliannagounder, V.K., Awasthi, G.P., Joshi, M.K., Park, C.H. \& Kim, C.S. 2021. Regenerated cellulose nanofiber reinforced chitosan hydrogel scaffolds for bone tissue engineering. Carbohydr. Polym. 251: 117023.

Medronho, B., Romano, A., Miguel, M.G., Stigsson, L. \& Lindman, B. 2012. Rationalizing cellulose (in)solubility: Reviewing basic physicochemical aspects and role of hydrophobic interactions. Cellulose 19: 581-587.

Mi, Q.Y., Ma, S.R., Yu, J., He, J.S. \& Zhang, J. 2016. Flexible and transparent cellulose aerogels with uniform nanoporous structure by a controlled regeneration process. ACS Sustain. Chem. Eng. 4: 656-660.

Mirtaghavi, A., Baldwin, A., Tanideh, N., Zarei, M., Muthuraj, R., Cao, Y., Zhao, G., Geng, J., Jin, H. \& Luo, J. 2020. Crosslinked porous three-dimensional cellulose nano fi bers- 
gelatine biocomposite scaffolds for tissue regeneration. Int J. Biol. Macromol. 164: 1949-1959.

Moon, R.J., Martini, A., Nairn, J., Simonsen, J. \& Youngblood, J. 2011. Cellulose nanomaterials review: Structure, properties and nanocomposites. Chemical Society Reviews 40: 39413994.

Nagel, M.C.V., Koschella, A., Voiges, K., Mischnick, P. \& Heinze, T. 2010. Homogeneous methylation of wood pulp cellulose dissolved in $\mathrm{LiOH} / \mathrm{urea} / \mathrm{H} 2 \mathrm{O}$. Eur. Polym. J. 46: 1726-1735.

O'Sullivan, A.C. 1997. Cellulose: The structure slowly unravels. Cellulose 4: 173-207.

Padzil, F.N.M., Gan, S., Zakaria, S., Mohamad, S.F., Mohamed, N.H., Seo, Y.B. \& Ellis, A.V. 2018. Increased solubility of plant core pulp cellulose for regenerated hydrogels through electron beam irradiation. Cellulose 25: 49935006.

Padzil, F.N.M., Zakaria, S., Chia, C.H., Jaafar, S.N.S., Kaco, H., Gan, S. \& Ng, P. 2015. Effect of acid hydrolysis on regenerated kenaf core membrane produced using aqueous alkaline-urea systems. Carbohydr. Polym. 124: 164-171.

Pal, K., Banthia, A. \& Majumdar, D. 2009. Polymeric hydrogels: Characterization and biomedical applications. Des. Monomers Polym. 12: 197-220.

Park, S., Baker, J.O., Himmel, M.E., Parilla, P.A. \& Johnson, D.K. 2010. Cellulose crystallinity index: Measurement techniques and their impact on interpreting cellulase performance. Biotechnol. Biofuels 3: 1-10.

Payen, M. 1838. Mémoire sur la composition du tissu propre des plantes et du ligneux. Comptes-rendus l'académie des Sci. 7: 1052-1057.

Petitpas, T. 1948. Etude de l'alcali-cellulose: Variations de structure de la cellulose dans les lessives alcalines. Compterendu du Lab. Cent. des Serv. Chim-iques l'Etat 226: 139147.

Philipp, B., Schleicher, H. \& Wagenknecht, W. 1977. Nonaqueous solvents of cellulose. Cellul. Chem. Technol. 48: 278-297.

Pierre, A.C. 2011. History of aerogels. In Advances in Sol-Gel Derived Materials and Technologies, edited by Aegerter, M.A. \& Prassas, M. New York: Springer. pp. 3-18.

Pottathara, Y.B., Bobnar, V., Finšgar, M., Grohens, Y., Thomas, S. \& Kokol, V. 2018. Cellulose nanofibrils-reduced graphene oxide xerogels and cryogels for dielectric and electrochemical storage applications. Polymer (Guildf) 147: 260-270

Qi, H., Liebert, T., Meister, F. \& Heinze, T. 2009. Homogenous carboxymethylation of cellulose in the $\mathrm{NaOH} /$ urea aqueous solution. React. Funct. Polym. 69: 779-784.

Salleh, K.M., Zakaria, S., Gan, S., Baharin, K.W., Ibrahim, N.A. \& Zamzamin, R. 2020. Interconnected macropores cryogel with nano-thin crosslinked network regenerated cellulose. Int. J. Biol. Macromol. 148: 11-19.

Salleh, K.M., Zakaria, S., Sajab, M.S., Gan, S. \& Kaco, H. 2019. Superabsorbent hydrogel from oil palm empty fruit bunch cellulose and sodium carboxymethylcellulose. Int. J. Biol. Macromol. 131: 50-59.

Salleh, K.M., Zakaria, S., Sajab, M.S., Gan, S., Chia, C.H., Jaafar, S.N. \& Amran, U.A. 2018. Chemically crosslinked hydrogel and its driving force towards superabsorbent behaviour. Int. J. Biol. Macromol. 118: 1422-1430.

Sannino, A., Demitri, C. \& Madaghiele, M. 2009. Biodegradable cellulose-based hydrogels: Design and applications. Materials (Basel) 2: 353-373.

Sarko, A., Southwick, J. \& Hayashi, J. 1976. Packing analysis of carbohydrates and polysaccharides. 7. Crystal structure of cellulose IIII and its relationship to other cellulose polymorphs. Macromolecules 9: 857-863.

Sen, S., Martin, J.D. \& Argyropoulos, D.S. 2013. Review of cellulose non-derivatizing solvent interactions with emphasis on activity in inorganic molten salt hydrates. $A C S$ Sustain. Chem. Eng. 1: 858-870.

Sescousse, R., Gavillon, R. \& Budtova, T. 2011. Aerocellulose from cellulose-ionic liquid solutions: Preparation, properties and comparison with cellulose- $\mathrm{NaOH}$ and celluloseNMMO routes. Carbohydr. Polym. 83: 1766-1774.

Shen, Q., 2010. Surface properties of cellulose and cellulose derivatives: A review. In Model Cellulose Surface, edited by Roman, M. Oxford: Oxford University Press. pp. 259289.

Sixta, H. 2006. Handbook of Pulp. Weinheim: Wiley-VCH Verlag $\mathrm{GmbH} \& \mathrm{Co} . \mathrm{KGaA}$

Sobue, H., Kiessig, H. \& Hess, K. 1939. Das system cellulosenatriumhydroxyd-wasser in abhängigkeit von der temperatur. Zeitschrift für Phys. Chemie 43: 309-328.

Stergar, J. \& Maver, U. 2016. Review of aerogel-based materials in biomedical applications. J. Sol-Gel Sci. Technol. 77: 738-752.

Swatloski, R.P., Spear, S.K., Holbrey, J.D. \& Rogers, R.D. 2002. Dissolution of cellose with ionic liquids. J. Am. Chem. Soc. 124: 4974-4975.

Tamon, H. \& Ishizaka, H. 1999. Preparation of organic mesoporous gel by supercritical/freeze drying. Dry. Technol. 17: 1653-1665.

Tamon, H., Ishizaka, H., Yamamoto, T. \& Suzuki, T. 2001. Freeze drying for preparation of aerogel-like carbon. Dry. Technol. 19: 313-324.

Tamon, H., Ishizaka, H., Mikami, M. \& Okazaki, M. 1997. Porous structure of organic and carbon aerogels synthesized by sol-gel polycondensation of resorcinol with formaldehyde. Carbon 35: 791-796.

Liebert, T.F., Heinze, T.J. \& Edgar, K.J. 2010. Cellulose Solvents: For Analysis, Shaping and Chemical Modification. ACS Division of Cellulose and Renewable Materials.

VanBemmelen, J.M. 1894. Der Hydrogel und das kristallinische Hydrat des Kupferoxydes. Zeitschrift für Anorg. und Allg. Chemie 5: 466.

Vyas, C., Poologasundarampillai, G., Hoyland, J. \& Bartolo, P. 2017. 3D Printing of Biocomposites for Osteochondral Tissue Engineering. 2nd ed. Biomedical Composites. Elsevier Ltd. 
Wang, R., Shou, D., Lv, O., Kong, Y., Deng, L. \& Shen, J. 2017. pH-Controlled drug delivery with hybrid aerogel of chitosan, carboxymethyl cellulose and graphene oxide as the carrier. Int. J. Biol. Macromol. 103: 248-253.

Wang, Y. 2008. Cellulose Fiber Dissolution in Sodium Hydroxide Solution at Low Temperature: Dissolution Kinetics and Solubility Improvement. Georgia Institute of Technology.

Wichterle, O. \& Lim, D. 1960. Hydrophilic gels for biological use. Nature 185: 117-129.

Wolfrom, M.L. 1955. Advances in Carbohydrate Chemistry. New York: Acad. Press Inc. p. 10.

Yahia, L.H., Chirani, N., Gritsch, L., Motta, F.L. \& Natta, C.G. 2015. History and applications of hydrogels. iMedPub Journals 4: 1-23.

Yamasaki, S., Sakuma, W., Yasui, H., Daicho, K., Saito, T., Fujisawa, S., Isogai, A. \& Kanamori, K. 2019. Nanocellulose xerogels with high porosities and large specific surface areas. Front. Chem. 7: 1-8.

Zhang, L., Ruan, D. \& Gao, S. 2002. Dissolution and regeneration of cellulose in $\mathrm{NaOH} /$ Thiourea aqueous solution. J. Polym. Sci. Part B Polym. Phys. 40: 1521-1529.

Zhou, J. \& Zhang, L. 2000. Solubility of cellulose in $\mathrm{NaOH} /$ urea aqueous solution. Polym. J. 32: 866-870.

Zhou, J., Chang, C., Zhang, R. \& Zhang, L. 2007. Hydrogels prepared from unsubstituted cellulose in $\mathrm{NaOH} /$ urea aqueous solution. Macromol. Biosci. 7: 804-809.
Zhou, J., Zhang, L. \& Cai, J. 2004. Behavior of cellulose in $\mathrm{NaOH} /$ urea aqueous solution characterized by light scattering and viscometry. J. Polym. Sci. Part B Polym. Phys. 42: 347-353.

Kushairi Mohd Salleh, Sarani Zakaria*, Marhaini Mostapha, Umar Adli Amran \& Nur Ain Ibrahim

Bioresource \& Biorefinery Research Group

Faculty of Science and Technology

Universiti Kebangsaan Malaysia

43600 UKM Bangi, Selangor Darul Ehsan

Malaysia

Wan Noor Aidawati Wan Nadhari

Malaysian Institute of Chemical and Bioengineering Technology Universiti Kuala Lumpur

Lot 1988 Kawasan Perindustrian Bandar Vendor

Taboh Naning

78000 Alor Gajah, Melaka

Malaysia

*Pengarang untuk surat-menyurat; email: szakaria@ukm.edu.my

Diserahkan: 2 Disember 2020

Diterima: 22 Februari 2021 